\title{
Extensive Amplification of Human Regulatory T Cells Alters Their Functional Capacities and Targets Them to the Periphery
}

\author{
Gunter Rappl, ${ }^{1}$ Annette Schmidt, ${ }^{2}$ Cornelia Mauch, ${ }^{3,4}$ Andreas A. Hombach, ${ }^{1}$ and Hinrich Abken ${ }^{1,4}$
}

\begin{abstract}
Repetitive antigen encounters together with a strong CD28 co-stimulatory signal were recently identified as driving extensive amplification of human regulatory $\mathrm{T}$ (Treg) cells; however, the consequences of this on the functional capacities of Treg cells remain unknown. In this report, we reveal that T cell receptor (TCR)/CD28triggered amplification in vitro converts $\mathrm{CD} 4{ }^{+} \mathrm{CD} 25^{\text {high }} \mathrm{FoxP}^{+}$Treg cells into a late memory phenotype associated with immunosenescence and loss of CD7. Accordingly, ex vivo-isolated CD7 ${ }^{-}$Treg cells have shortened telomeres and decreased telomerase expression compared to the majority of "mature" CD7 ${ }^{+}$Treg cells. Although they resist spontaneous apoptosis, amplified $\mathrm{CD}^{-}$Treg cells exhibit increased sensitivity to activationinduced cell death (AICD). Extensive amplification of Treg cells is, moreover, accompanied by an increased activation threshold, reduced suppressor capacities, and interleukin-10 (IL-10) secretion, but secretion of high amounts of IL-4. Concomitantly, amplified Treg cells express homing receptors targeting them to the periphery. This is confirmed in vivo by the extensive accumulation of $\mathrm{CD}^{-}$Treg cells with shortened telomeres in chronic inflammatory skin lesions, including atopic dermatitis and lichen ruber. Our data indicate that extensive amplification upon repetitive TCR/CD28 engagement alters the functional capacities of CD $4{ }^{+} \mathrm{CD} 25^{\text {high }}$ Treg cells toward less suppressive cells, but potential mediators in sustaining inflammatory reactions through IL-4.
\end{abstract}

Introduction

$\mathbf{T}$ REgulatory (TREg) CElls ARE KEy PlAyers in the establishment and maintenance of peripheral tolerance. ${ }^{1}$ Upon differentiation in the thymus, CD4 ${ }^{+} \mathrm{CD} 25^{\text {high }}$ Treg cells are exported in a naïve-like status into the circulation where they execute their suppressive functions, i.e., inhibition of extensive polyclonal T cell activation and control of self-reactive $\mathrm{T}$ cells that have escaped thymic negative selection. Alternatively, Treg cells can be generated in the periphery by conversion of nonregulatory naïve and memory $\mathrm{T}$ cells. ${ }^{2}$ Treg cells enter terminal differentiation and proliferation upon long-lasting, repetitive stimulation, which was most recently identified to be delivered by T cell receptor (TCR) engagement plus a strong CD28 co-stimulatory signal. ${ }^{3}$ The functional capacities of Treg cells in an advanced proliferative stage, in terminal differentiation or in immunosenescence, however, remain to be elucidated.
On the other hand, several protocols for amplifying human Treg cells in vitro have been reported. ${ }^{4-6}$ Assuming that the functional capacities of Treg cells are adequately conserved upon extensive proliferation, ex vivo-amplified Treg cells are expected to be of therapeutic value upon adoptive transfer. This will particularly be the case when absence or dysfunction of Treg cells leads to immune-mediated pathologies, including autoimmunity, allergies, and graft rejection. ${ }^{6-8}$ Restoration of Treg cell numbers and/or function are expected to ameliorate disease, and there is great hope that ex vivo-amplified Treg cells upon adoptive transfer will execute their suppressor functions as do mature, freshly isolated Treg cells. ${ }^{9}$ Again, the consequences of extensive amplification on the functional capacities of Treg cells have so far not been explored.

One of the earliest markers in T cell ontogeny is CD7, a glycosaminoglycan, which is expressed on the majority of peripheral blood T cells, natural killer (NK) cells, and all thy-

\footnotetext{
${ }^{1}$ Tumorgenetics, Department of Internal Medicine I, University of Cologne, Cologne, Germany.

${ }^{2}$ Institute for Circulation Research and Sports Medicine, German Sports University, Cologne, Germany.

${ }^{3}$ Tumorbiology, Department of Dermatology, University of Cologne, Cologne, Germany.

${ }^{4}$ Center for Molecular Medicine Cologne (CMMC), University of Cologne, Cologne, Germany.
} 
mocytes. CD7, hence, has been widely used as a marker for posthymic $\mathrm{T}$ cells and for the diagnosis of malignancies in the early T cell development. ${ }^{10}$ Previously, we reported that lack of CD7 expression represents a stable phenotype of $\mathrm{CD}^{+}{ }^{+} \mathrm{CD}^{-} \mathrm{T}$ cell clones during long-term propagation for several months in vitro. ${ }^{11}$ Because the majority of $\mathrm{CD}^{+} \mathrm{T}$ cells that lack CD7 expression exhibit the $\mathrm{CD}_{45 \mathrm{RO}} \mathrm{CD}^{+} 5 \mathrm{RA}^{-}$ memory phenotype, lack of CD7 expression may reflect a differentiation state associated with the late immune response. ${ }^{11}$

Using loss of CD7 as a surrogate marker, we reveal here that prolonged TCR-triggered amplification of human Treg cells results in altered functional capacities, including reduced suppressor activities, entry into immunosenescence, and expression of homing receptors targeting them to the periphery. Accordingly, we found extensively amplified Treg cells accumulated in chronic inflammatory lesions in the peripheral organs in vivo where repetitive antigen encounter occurs. In addition to reduced suppressor capacities, it is interesting that proliferative advanced Treg cells secrete high amounts of IL-4, which converts them to potential mediators in sustaining chronic inflammatory reactions.

\section{Materials and Methods}

\section{Human subjects}

Healthy young blood donors were recruited for this study ( $n=30$; mean $30 \pm 10$ years), and buffy coats were obtained from the University of Cologne blood bank (Cologne, Germany). Subjects who were taking immunosuppressive drugs or who had a disease potentially affecting the immune system were excluded. All blood samples were taken with informed consent. The work was approved by the institutional review committee of the University of Cologne. The frequency of $\mathrm{CD}^{-} \mathrm{T}$ cells was the same in both sexes of the blood donors.

\section{Antibodies, cytokines, and flow cytometric analyses}

Fluorochrome-conjugated monoclonal antibodies were used according to the manufactor's recommendations. OKT3 (ATCC CRL 8001) is a hybridoma cell line that produces the anti-CD3 monoclonal antibody (mAb) OKT3; 15E8 hybridoma cells ${ }^{12}$ produce the anti-CD28 mAb 15E8. To detect surface and intracellular cytotoxic T lymphocyte antigen- 4 (CTLA-4) expression, cells were stained with the phycoerythrin (PE)-conjugated anti-CTLA-4 mAb BNI3 (BD Biosciences, Heidelberg, Germany) as described. ${ }^{13}$ To analyze intracellular interleukin-2 (IL-2) or IL-4 expression upon stimulation, cells were activated, fixed, and permeabilized as described ${ }^{13}$ and stained with the PE-conjugated anti-IL-2 mAb MQ1-17H12 (Biolegend, Eching, Germany) or anti-IL$4 \mathrm{mAb}$ 8D4-8 (Biolegend). To monitor killer cell lectin-like receptor G1 (KLRG-1) expression, cells were stained with Alexa-488-conjugated mouse anti-human KLRG-1 mAb clone 13A2 (kindly provided by H.P. Pircher, Institute of Immunology, Freiburg, Germany). For galectin-10 detection, cells were stained with the mouse anti-human galectin-10 mAb B-F42 (Diaclone, Cologne, Germany) as described. ${ }^{14}$ To monitor FoxP3 expression, cells were stained with the antihuman FoxP3 mAb 150D/E4 (kindly provided by Dr. A. Banham, Oxford, UK) as described. ${ }^{15}$ Alternatively, cells were stained with the allophycocyanin (APC)-conjugated antiFoxP3 mAb 3G3 (Miltenyi Biotec, Bergisch Gladbach, Germany). Cells were analyzed by flow cytometry using fluorescence-activated cell sorting (FACS; FACS Calibur or a FACS Canto flow cytometer, BD Biosciences). Viable lymphocytes were gated on the basis of forward/side scatter and negative 7-amino-actinomycin D (7-AAD) staining. Human recombinant (r) IL-2, IL-4, IL-10, IL-15, tumor growth factor$\beta 1$ (TGF- $\beta 1$ ), and interferon- $\gamma$ (IFN- $\gamma$ ) were purchased from R\&D Systems (Wiesbaden, Germany).

\section{Preparative isolation of $C D 4^{+} T$ cell subpopulations}

Peripheral blood mononuclear cells (PBMCs) were isolated from healthy donors after informed consent. $\mathrm{CD}^{+}{ }^{+} \mathrm{CD} 45 \mathrm{RO}^{+} \mathrm{T}$ cells were obtained by negative depletion during magnetic cell sorting (MACS) procedures using the $\mathrm{CD}^{+}$memory $\mathrm{T}$ cell isolation kit (Miltenyi Biotec). Isolated memory $\mathrm{T}$ cells were separated into $\mathrm{CD}^{+}$and $\mathrm{CD}^{-}$subpopulations by an additional MACS separation step using the PE-conjugated anti-CD7 mAb CD7-6B7 (CALTAG, Hamburg, Germany) and anti-PE multisort beads (Miltenyi Biotec). After microbead removal using a "multisort-release reagent" (Miltenyi Biotec), $\mathrm{CD}^{-}$and $\mathrm{CD}^{+} \mathrm{T}$ cells were further separated according to their CD25 expression using antiCD25 microbeads (Miltenyi Biotec).

Because some studies report problems with the regulatory nature of MACS-sorted Treg cells, e.g., that they are anergic, but not suppressive, ${ }^{16}$ we isolated by two alternative procedures: $\mathrm{CD} 4{ }^{+} \mathrm{CD} 25^{\text {high }} \mathrm{T}$ cells by FACS sorting. $\mathrm{CD} 4{ }^{+} \mathrm{CD} 45 \mathrm{RO}^{+}$ cells were isolated from PBMCs by negative depletion and in a second step according to their CD25 expression by MACS techniques using the 'human regulatory $\mathrm{T}$ cell isolation kit' and anti-CD45RA microbeads (Miltenyi Biotec). Isolated CD25 $5^{\text {high }}$ and $\mathrm{CD} 25^{-} \mathrm{T}$ cells were stained with the PE-Alexa700-conjugated anti-CD7 mAb CD7-6B7 (CALTAG) and separated into $\mathrm{CD}^{+}$and $\mathrm{CD}^{-}$subpopulations using a FACS Aria cell sorter (BD Biosciences).

Alternatively, $\mathrm{CD}^{+} \mathrm{T}$ cells with high CD25 expression $\left(\mathrm{CD} 4^{+} \mathrm{CD} 25^{\text {high }}\right)$ were isolated by MACS combined with FACS sorting, as reported previously. ${ }^{16} \mathrm{CD}^{+} \mathrm{CD}^{+} 5 \mathrm{RO}^{+} \mathrm{T}$ cells were obtained by negative depletion by MACS procedures using the $\mathrm{CD}^{+}{ }^{+}$memory $\mathrm{T}$ cell isolation kit (Miltenyi Biotec). Isolated memory T cells were separated into $\mathrm{CD}^{+}$ and $\mathrm{CD}^{-}$subpopulations by additional MACS separation using the fluorescein isothiocyanate (FITC)-conjugated antiCD7 mAb 4H9 (BD Biosciences) and anti-FITC microbeads (Miltenyi Biotec). Half of the isolated $\mathrm{CD}^{+}$and $\mathrm{CD}^{-} \mathrm{T}$ cells were stained with the PE-conjugated anti-CD25 mAb MA251 (BD Biosciences) and separated into CD25 high and CD25- subpopulations using a FACS Aria cell sorter (BD Biosciences) or were incubated with $4 \mu \mathrm{L}$ of anti-CD25 beads per $10^{7}$ cells for MACS isolation of CD25 high $\mathrm{T}$ cells.

The purity of MACS-sorted CD $4{ }^{+} \mathrm{CD} 25^{+}$and $\mathrm{CD} 44^{+} \mathrm{CD} 25^{-} \mathrm{T}$ cells, as recorded by flow cytometry, was $98 \pm 1 \%$ and $89 \pm$ $2 \%$, respectively, and the purity of FACS-sorted cells was $>97 \%$. A typical isolation procedure starting from $5 \times 10^{8}$ mononuclear cells from the peripheral blood resulted in $5 \times$ $10^{6}$ purified $\mathrm{CD}^{+} \mathrm{CD}_{25}^{+}, 3 \times 10^{7} \mathrm{CD}^{+} \mathrm{CD}^{+} 5^{-}, 3 \times 10^{5}$ $\mathrm{CD}^{-} \mathrm{CD}^{-} 5^{+}$, and $8 \times 10^{6} \mathrm{CD}^{-} \mathrm{CD}^{-} 5^{-} \mathrm{T}$ cells. No significant difference in the yield of MACS- or FACS-sorted T cell subsets was found. 


\section{Cytokine detection}

Cytokines in the culture medium were recorded by enzyme-linked immunosorbent assay (ELISA) using matched pairs of antibodies specific for IL-4 (clones 8D4-8 and MP425D2), IL-10 (clones JES3-9D7 and JES3-12G8), IFN- $\gamma$ (clones NIB 42 and B133.5), and TGF- $\beta 1$ (clones A75-2 and A75-3) (all purchased from BD Biosciences). The detection limits of the assays were $15 \mathrm{pg} / \mathrm{mL}$ IL-4, $15 \mathrm{pg} / \mathrm{mL}$ IL-10, $15 \mathrm{pg} / \mathrm{mL}$ IFN- $\gamma$, and $10 \mathrm{pg} / \mathrm{mL}$ TGF- $\beta 1$, respectively.

\section{Detection of apoptotic cells}

Apoptotic cells were assessed by FACS analysis using the Annexin-V Apoptosis Detection Kit (BD Biosciences). Viable cells were detected as cells negative for annexin- $V$ and 7AAD staining.

\section{Assay for suppressor activities}

Analysis of suppressor activities of $\mathrm{CD}^{-}$Treg cells and the corresponding $\mathrm{CD}^{+}$Treg cells were performed as described recently. ${ }^{3}$ In brief, freshly isolated CD45RO ${ }^{+} \mathrm{CD} 25^{-}$ $\mathrm{T}$ cells $\left(1 \times 10^{7}\right.$ cells $\left./ \mathrm{ml}\right)$ were labeled with 5 -carboxylfluorescein diacetate succinimidyl ester (CFSE) $(1 \mu \mathrm{M})$ (Molecular Probes, Göttingen, Germany) at room temperature for 3 min and washed three times in RPMI 1640 medium, 10\% (vol/vol) fetal calf serum (FCS). CFSE-labeled CD45RO ${ }^{+}$CD25 ${ }^{-}$ T cells $\left(1 \times 10^{5}\right.$ cells $)$ were stimulated with the agonistic antiCD3 mAb OKT3 $(10 \mu \mathrm{g} / \mathrm{mL})$ plus the anti-CD28 mAb 15E8 $(1 \mu \mathrm{g} / \mathrm{mL})$ in the presence of $1 \times 10^{5} \mathrm{CD} 45 \mathrm{RO}^{+} \mathrm{CD} 25^{+} \mathrm{T}$ cells or control cells, respectively. Cell proliferation was monitored by gating on viable cells and recording CFSE dilution after 6 days. In pilot experiments, CFSE-labeled cells in multiple rounds of proliferation were best detectable at day 6 . The unstained cells were excluded by gating as described previously. ${ }^{17}$ Representative histograms are shown to demonstrate the validity of the assay. To calculate the percentage of cells that is inhibited in cell division, the following formula was used:

$$
\begin{gathered}
100-\left[\left(\% \text { CFSE-positive CD }{ }^{+} \mathrm{CD} 45 \mathrm{RO}^{+} \mathrm{CD} 25^{-}\right.\right. \\
\mathrm{T} \text { cells in co-culture with } \mathrm{CD} 4^{+} \mathrm{CD} 45 \mathrm{RO}^{+} \mathrm{CD} 25^{+} \\
\text {cells or CD } \left.4^{+} \mathrm{CD} 45 \mathrm{RO}^{+} \mathrm{CD} 25^{-} \text {cells }\right) / \\
\left(\% \text { CFSE-positive CD } 4^{+} \mathrm{CD} 45 \mathrm{RO}^{+} \mathrm{CD} 25^{-}\right. \\
\mathrm{T} \text { cells only }) \times 100] .
\end{gathered}
$$

\section{Proliferation assay}

Cells $\left(10^{4}\right.$ cells $\left./ 100 \mu \mathrm{L}\right)$ were pulsed with bromodeoxyuridine (BrdU) for $6 \mathrm{hr}$ and assayed for BrdU incorporation by ELISA using the Cell proliferation ELISA BrdU kit (Roche Diagnostics, Mannheim, Germany). BrdU incorporation directly correlates with cell proliferation. ${ }^{18}$

\section{Telomere staining and analysis of telomerase expression}

Telomere lengths were determined by fluorescence in situ hybridization (FISH) using the Telomere PNA Kit/FITC for flow cytometry (DAKO Cytomation, Hamburg, Germany) as described recently. ${ }^{19}$ Jurkat cells with a known telomere length of $10 \pm 2 \mathrm{~kb}$ and 1301 CEM cells with telomere length of $30 \pm 3 \mathrm{~kb}$ served as standards. ${ }^{20,21}$ Naive CD4 ${ }^{+} \mathrm{CD}^{2} 5 \mathrm{RA}^{+}$ $\mathrm{T}$ cells were isolated by MACS using the CD4 ${ }^{+}$Naive T Cell Isolation kit (Miltenyi Biotec). Cells were analyzed by flow cytometry using a FACS Calibur (BD Biosciences) equipped with Cell Quest software. In biopsy sections, telomere lengths of individual cells were determined by quantitative fluorescence in situ hybridization (Q-FISH) using the Telomere PNA Kit/Cy3 for immunohistochemistry (DAKO Cytomation) as recently described. ${ }^{22}$ Multicolor immunofluorescence staining for CD4, CD7, and FoxP3 was performed as described. To record telomere-specific Cy3 fluorescence signals, regions of interest were gated around $\mathrm{Cy} 3$ spots and the mean fluorescence intensity of telomere spots (MFI/spot) was automatically quantified using the ImageJ software (U.S. National Institutes of Health). Telomerase expression was recorded by FACS analysis as recently described. ${ }^{19,23}$ Viable lymphocytes were gated based on forward/side scatter and negative 7-AAD staining.

\section{Immunohistochemistry}

Skin biopsies were snap-frozen in liquid nitrogen, processed for cryostat sections, and fixed with $4 \%$ (vol/vol) paraformaldehyde in phosphate-buffered saline (PBS) for 30 min at room temperature. Multicolor immunohistochemistry stainings were performed as described. ${ }^{24}$ Sections were stained overnight in Tris-buffered saline (TBS), $0.8 \%$ (wt/vt) bovine serum albumin (BSA) with the mouse anti-CD4 mAb 4B12 (immunoglobulin $\mathrm{G}_{1}\left[\mathrm{IgG}_{1}\right]$ ) (dilution 1:40) (Novocastra, Dossenheim, Germany), the mouse anti-CD7 mAb CBC.37 ( $\operatorname{IgG}_{2 \mathrm{~b}}$ ) (dilution 1:50) (DAKO Cytomation), antiCD25 mAb 4C9 (IgG $2 \mathrm{~b}$ ) (dilution 1:200) (Novocastra), polyclonal rabbit anti-human FoxP3 Ab ab10563 (dilution 1:800) (Abcam, Eching, Germany), and anti-CD127 mAb eBioRDR5 $\left(\mathrm{IgG}_{1}\right)$ (dilution 1:10) (eBiosciences, Frankfurt/Main, Germany), respectively. Slides were rinsed three times in TBS for $15 \mathrm{~min}$. The following secondary antibodies were used: Cy3-conjugated goat anti-mouse IgG, Cy2-conjugated goat anti-mouse IgG2, Cy2-conjugated goat anti-mouse IgG, Cy5conjugated goat anti-mouse IgG, and Cy5-conjugated goat anti-rabbit IgG (Jackson Immuno Research, West Grove, PA) in a 1:200 dilution for $1 \mathrm{hr}$ at room temperature. Slides were rinsed three times in TBS for $15 \mathrm{~min}$. For detection of multiple antigens, the slide was stained for the first antigen and blocked with TBS, 5\% (wt/vol) BSA for $1 \mathrm{hr}$ at room temperature before staining for the second antigen. Finally, slides were dehydrated, transferred into xylole, coverslipped with two drops of Entellan (ProSciTec, Thuringowa, Australia), and analyzed using the Zeiss Confocal Laser Scanning Microscope LSM 510 (Karl Zeiss, Oberkochen, Germany). Specificity of staining was assayed by incubation of the slides with the respective isotypematched control antibodies.

\section{Statistical analyses}

Data represent the mean \pm standard deviation (SD) of at least five independent experiments. Statistical analysis was performed using the two-tailed Student test or the paired $t$ test; $p<0.05$ was considered significant.

\section{Results}

\section{Extensive amplification of Treg cells generates CD7- Treg cells with reduced suppressor capacities}

We asked whether the phenotype and functional capacities of mature Treg cells are retained after extensive ampli- 

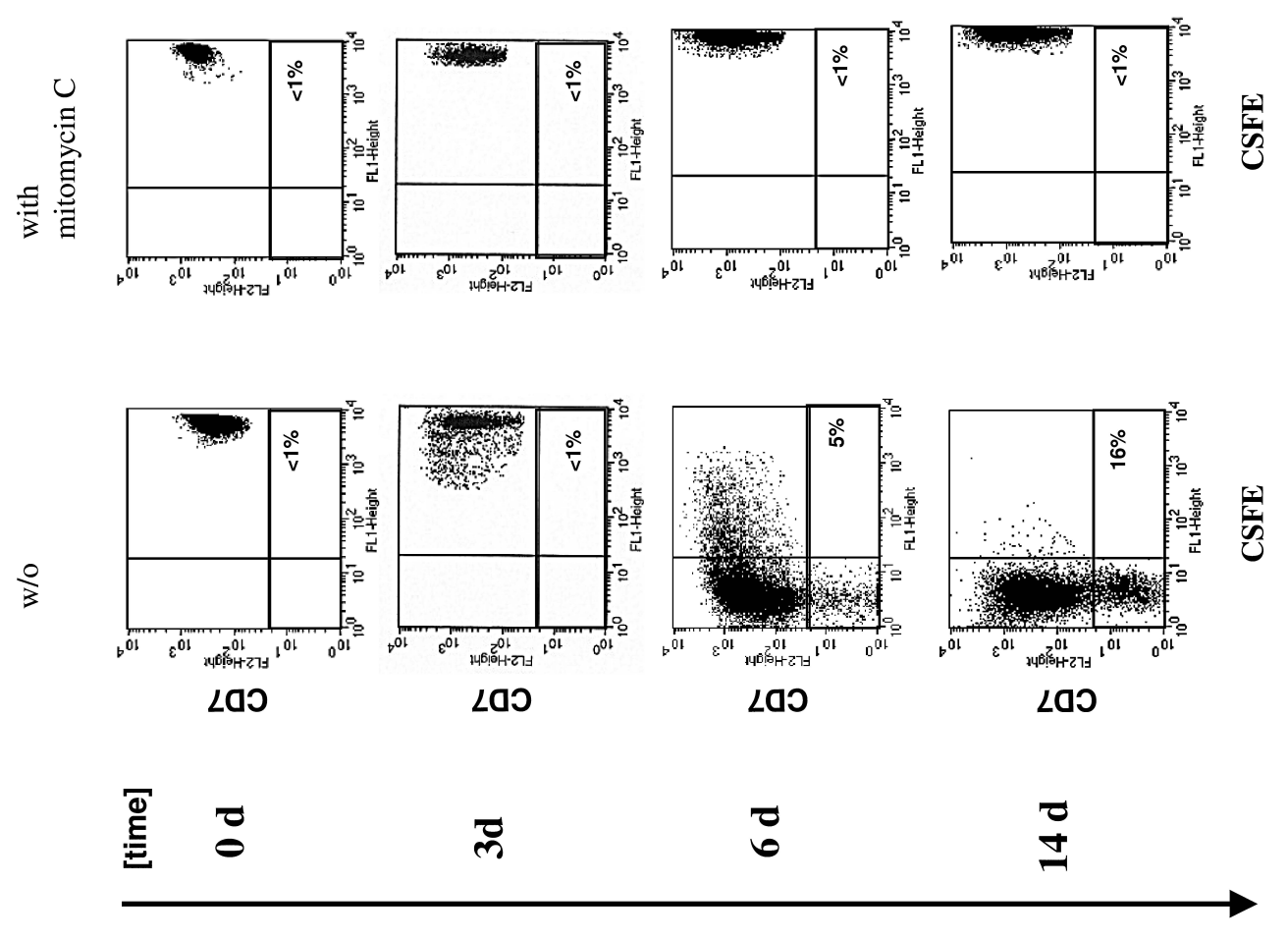

ก

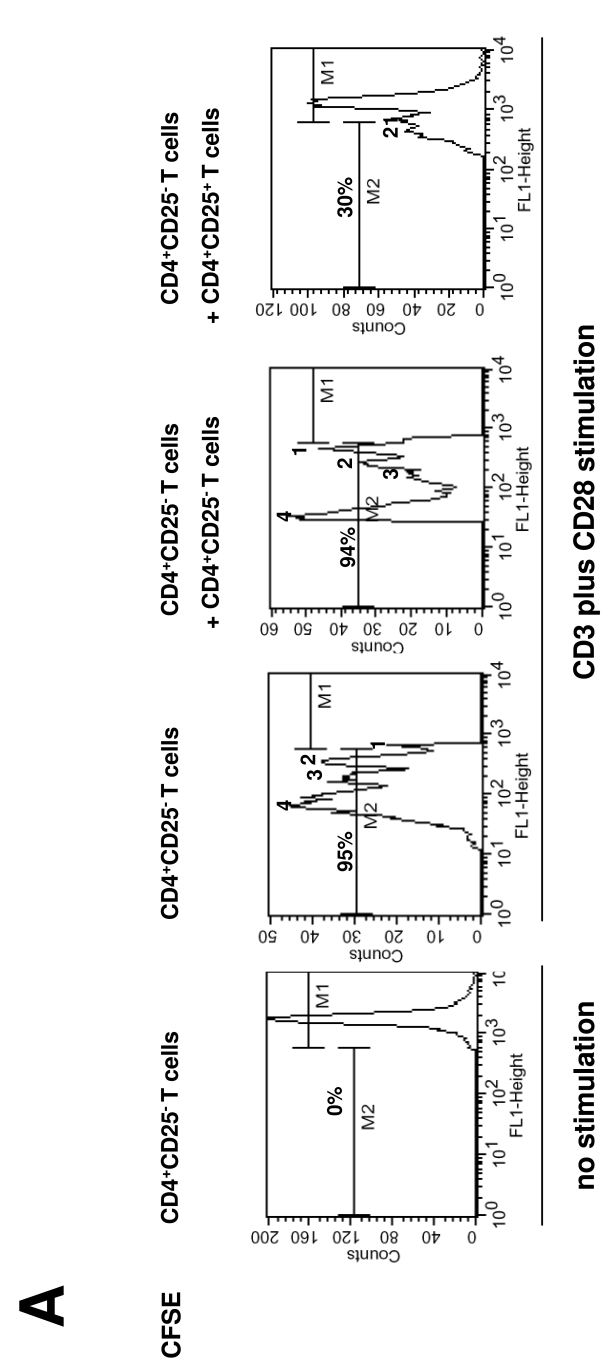

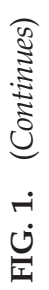
$\circ \stackrel{\circ}{\circ} \circ \stackrel{2}{\circ}$

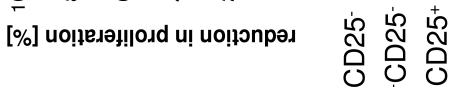
今ิ $\hat{⿱}^{+} \hat{D}^{+}$

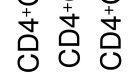
嵌 


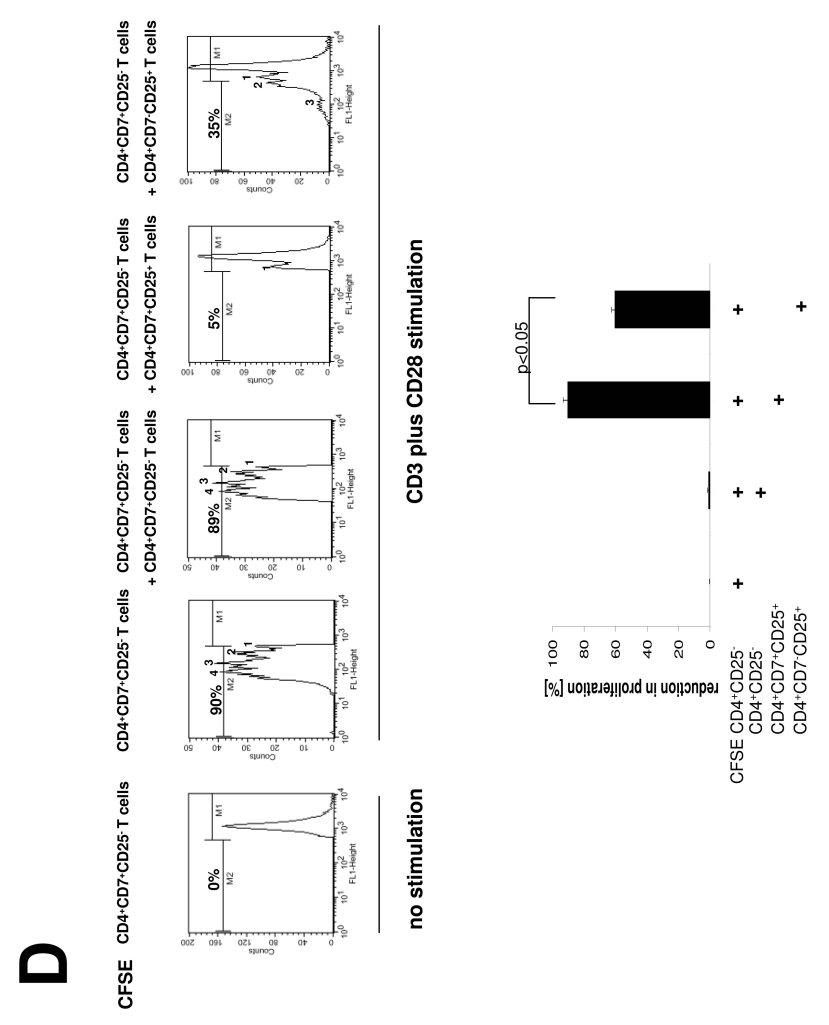

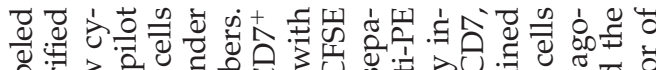

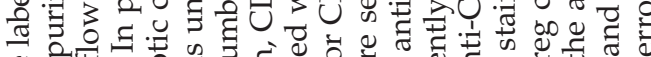

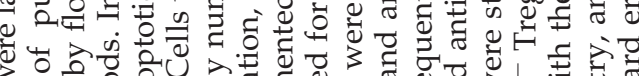

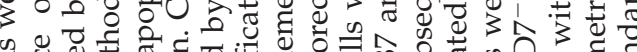

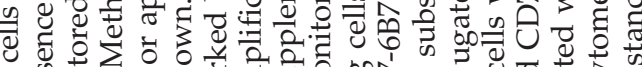

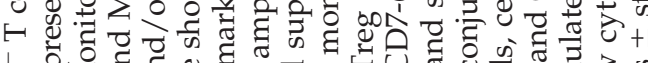

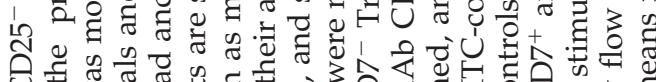

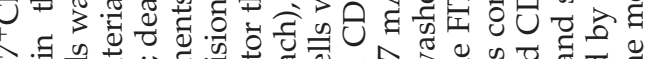

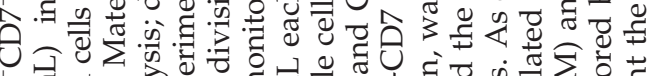

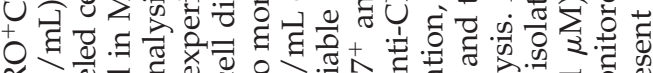

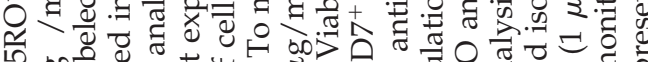

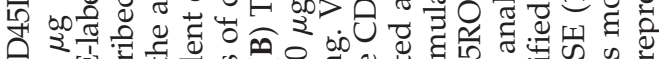

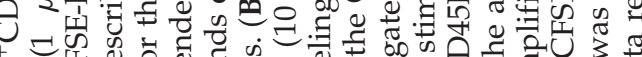

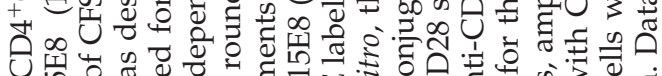

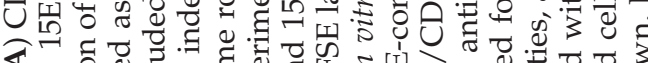

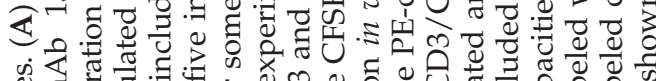
ن

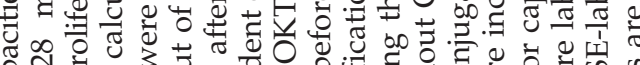

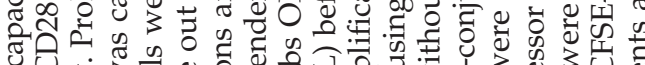

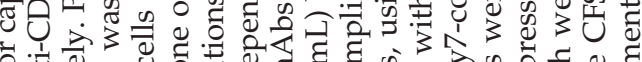

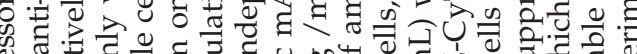
这

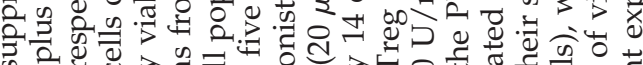

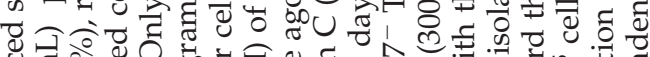

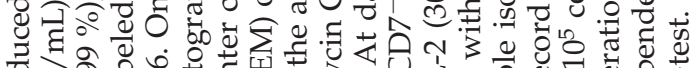

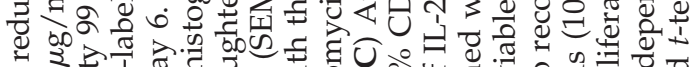

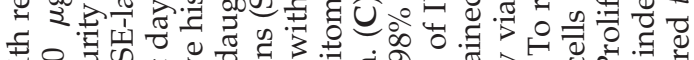

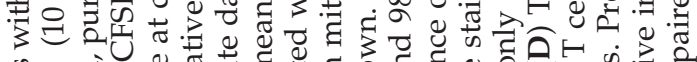

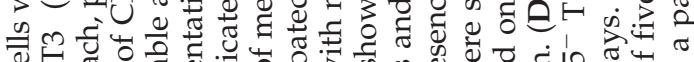
बै oo 0
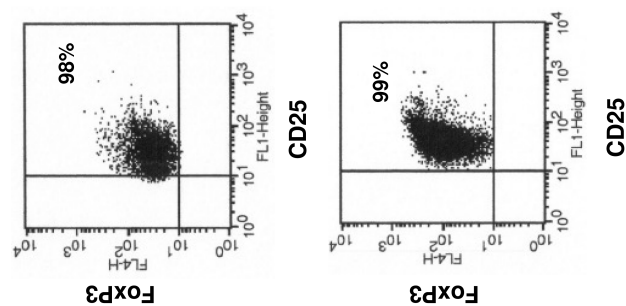

EdXo」
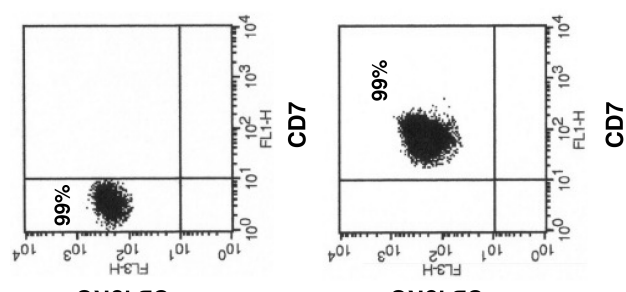

OyStaJ

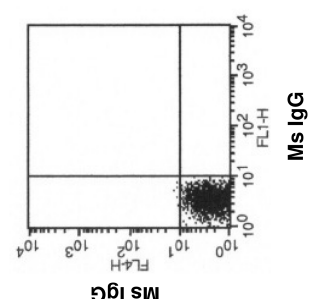

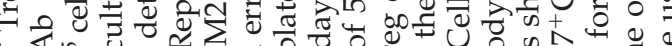

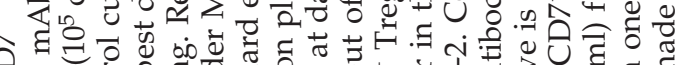
Oे

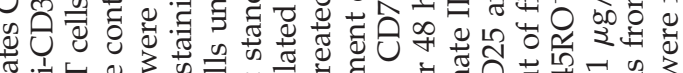
政

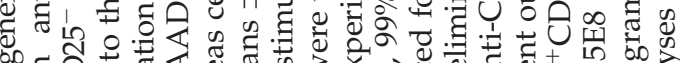
of 5

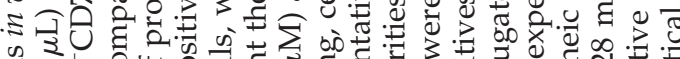

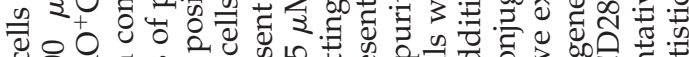
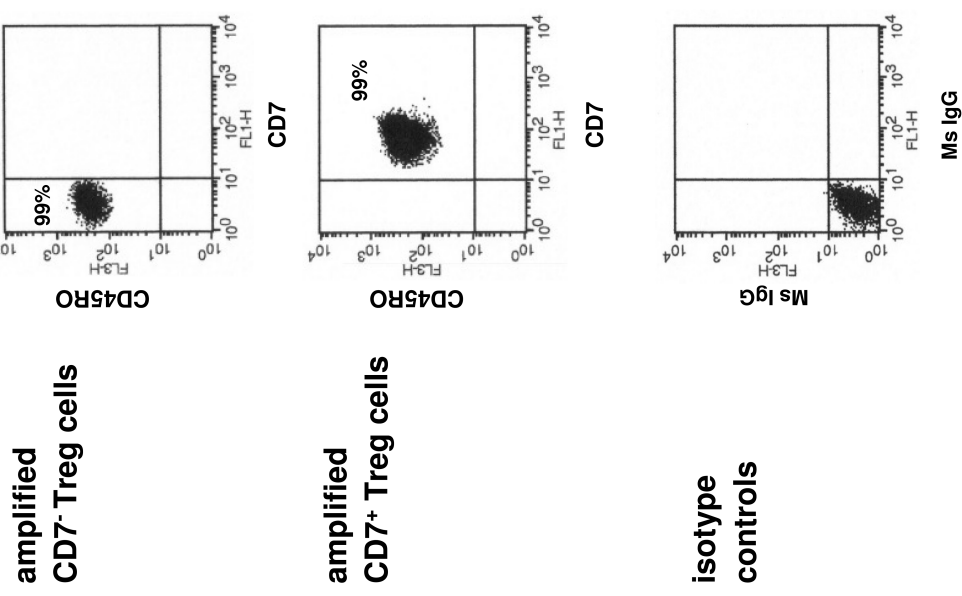
-

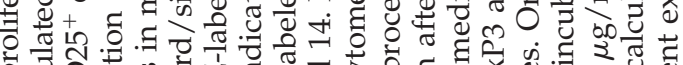
齐

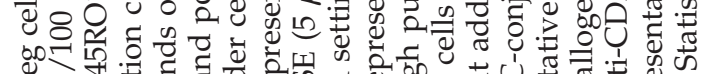

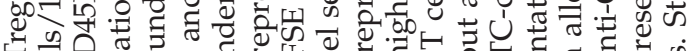

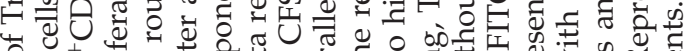

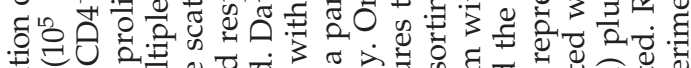

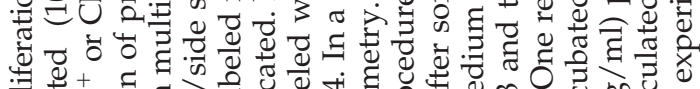

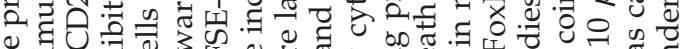

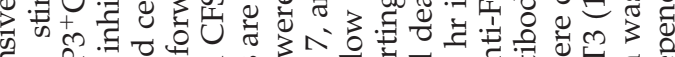

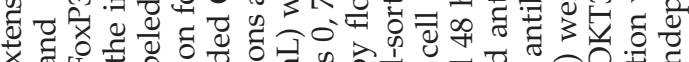

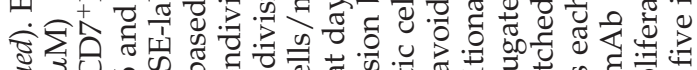

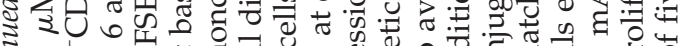

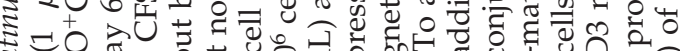

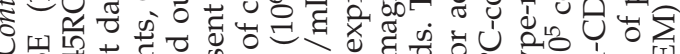

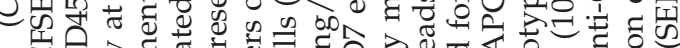

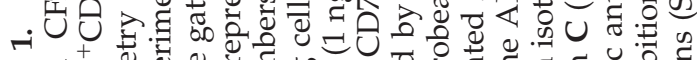

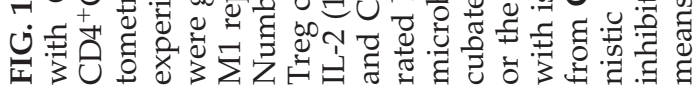


fication in vitro. $\mathrm{CD} 4^{+} \mathrm{CD} 45 \mathrm{RO}^{+} \mathrm{CD} 7^{+} \mathrm{FoxP}^{+} \mathrm{CD} 25^{+}$Treg cells were isolated from the peripheral blood to high purity. Their functional capacities were recorded by a CFSE-based suppression assay, which monitors up to five division cycles of CFSE-labeled CD4 ${ }^{+} \mathrm{CD} 25^{-}$responder cells within 6 days. Addition of Treg cells efficiently suppressed proliferation, whereas addition of $\mathrm{CD}^{+} \mathrm{CD} 25^{-} \mathrm{T}$ cells did not (Fig. 1A). Treg cells were induced to proliferate by CD3 and CD28 stimulation in the presence of IL-2, giving rise to about 10 cell doublings within 14 days. Proliferation was monitored by CFSE dilution of labeled mature CD7 ${ }^{+}$Treg cells (Fig. 1B). We used CD7 as additional marker to identify mature T cells, because $\mathrm{T}$ cells in late proliferative senescence lose CD7 expression. ${ }^{19}$ After 14 days of stimulation, about $5 \times 10^{5} \mathrm{CD}^{-}-$ $\mathrm{CD}_{25}{ }^{+} \mathrm{T}$ cells were generated from $5 \times 10^{6} \mathrm{CD}^{+} \mathrm{CD} 25^{+}$ Treg cells. Proliferation is required to generate $\mathrm{CD}^{-}$Treg cells because blocking cell division by mitomycin $\mathrm{C}$ prevented generation of $\mathrm{CD}^{-}$cells from $\mathrm{CD}^{+}$Treg cells. Both, $\mathrm{CD}^{+}$and CD7 ${ }^{-}$Treg cells retained FoxP3 and CD25 high expression upon amplification (Fig. 1C), although FoxP3 expression was lower in $\mathrm{CD}^{-}$compared to $\mathrm{CD}^{+}$Treg cells (MFI 120.41 vs. 298.14). Amplified CD7 ${ }^{-}$Treg cells suppressed proliferation of allogeneic $\mathrm{CD} 4^{+} \mathrm{CD} 45 \mathrm{RO}{ }^{+} \mathrm{CD} 25^{-} \mathrm{T}$ cells with significantly lower capacities than amplified $\mathrm{CD}^{+}$ Treg cells (Fig. 1D). Suppressor activity is specific because $\mathrm{CD} 4{ }^{+} \mathrm{CD} 25^{-} \mathrm{T}$ cells did not inhibit proliferation of the allogeneic responder cells. Taken together, extensive amplification of peripheral blood $\mathrm{CD}^{+}$Treg cells in vitro generates $\mathrm{CD}^{-}$Treg cells with reduced suppressor capacities.

\section{$C D 7^{-}$Treg cells in the peripheral blood represent late memory Treg cells}

Flow cytometric analyses of Treg cells in the peripheral blood revealed that the $\mathrm{CD} 4{ }^{+} \mathrm{CD} 25^{\text {high }}-\mathrm{FoxP}^{+} \mathrm{T}$ cell population harbored a subset of $9.5 \% \pm 7.5 \%$ cells, which in contrast to the majority of T cells, did not express CD7 (Fig. 2A). Both the $\mathrm{CD}^{+}$and $\mathrm{CD}^{-}$subsets of $\mathrm{CD} 4^{+} \mathrm{CD} 45 \mathrm{RO}^{+} \mathrm{CD} 25^{\text {high }}$ $\mathrm{T}$ cells expressed FoxP3, although in significantly lower levels in $\mathrm{CD}^{-}$Treg cells compared to $\mathrm{CD}^{+}$Treg cells, i.e., MFI 110.46 vs. 252.81 . $\mathrm{CD}^{+}{ }^{+} \mathrm{CD} 45 \mathrm{RO}^{+} \mathrm{CD} 25^{-} \mathrm{T}$ cells as control did not express FoxP3.

$\mathrm{CD}^{-}$and $\mathrm{CD}^{+}$cells of the $\mathrm{CD}^{+} \mathrm{CD} 45 \mathrm{RO}^{+} \mathrm{CD} 25^{\text {high }}$ Treg cell population were isolated to high purities from the peripheral blood by two alternative sorting procedures. First, $\mathrm{CD}^{+}{ }^{+} \mathrm{CD} 45 \mathrm{RO}^{+} \mathrm{T}$ cells were isolated by negative magnetic sorting and $\mathrm{CD}^{+}$and $\mathrm{CD}^{-} \mathrm{T}$ cells subsequently separated by positive enrichment of $\mathrm{CD}^{+}$cells. $\mathrm{CD} 25^{\text {high }} \mathrm{T}$ cells in the respective subsets were finally isolated by positive enrichment resulting in highly purified $\mathrm{CD}^{+}$and $\mathrm{CD}^{-}$subset cells of the $\mathrm{CD} 4{ }^{+} \mathrm{CD} 45 \mathrm{RO}^{+} \mathrm{CD} 25^{\text {high }} \mathrm{T}$ cell population (Fig. 2B). FoxP3 was expressed in more than $95 \%$ of these cells.

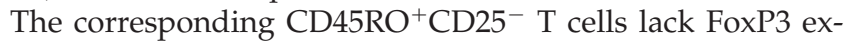
pression, whereas some $\mathrm{T}$ cells with intermediate CD25 expression expressed FoxP3 as well, which is in agreement with recently published data. ${ }^{15}$ By an alternative cell isolation procedure, we first enriched $\mathrm{CD} 4{ }^{+} \mathrm{CD} 45 \mathrm{RO}{ }^{+} \mathrm{CD} 25^{\text {high }} \mathrm{T}$ cells by magnetic cell sorting and subsequently isolated the $\mathrm{CD}^{+}$and $\mathrm{CD}^{-}$subpopulations by FACS, or enriched $\mathrm{CD}^{+}{ }^{+} \mathrm{CD} 45 \mathrm{RO}^{+} \mathrm{CD}^{+}{ }^{+}$and $\mathrm{CD} 4{ }^{+} \mathrm{CD} 45 \mathrm{RO}^{+} \mathrm{CD}^{-} \mathrm{T}$ cells by magnetic cell sorting, followed by isolation of the corresponding CD25 high and CD25- $5^{-}$subpopulations by flow cy- tometric sorting. In this study, both MACS- and FACS-based separation procedures were used to isolate $\mathrm{CD} 4^{+} \mathrm{CD} 25^{\text {high- }}$ FoxP3 $^{+} \mathrm{T}$ cells and their subpopulations, and both isolation procedures generated Treg cell subpopulations with similar functional capacities, i.e., proliferation, suppressor activity, cytokine secretion, and apoptosis sensitivity.

Both $\mathrm{CD}^{-}$and $\mathrm{CD}^{+}$subset cells of the ex vivo-isolated $\mathrm{CD}^{+}{ }^{+} \mathrm{CD} 45 \mathrm{RO}^{+} \mathrm{CD} 25^{\text {high }}$ Treg cell population suppressed proliferation of autologous $\mathrm{CD}^{+} \mathrm{CD} 45 \mathrm{RO}^{+} \mathrm{CD} 25^{-} \mathrm{T}$ cells (Fig. 3A). CD7 ${ }^{-}$Treg cells, however, exhibited significantly lower suppressor capacities toward the same target cells than the corresponding $\mathrm{CD}^{+}$Treg cells. Titration analyses revealed that a suppressor to responder cell ratio of 1:1 resulted in maximal suppressor activities of both $\mathrm{CD}^{+}$and $\mathrm{CD}^{-}$ Treg cells (Fig. 3B). The same ratio is known for mature Treg cells. ${ }^{13}$ Suppressor activity is specific because $\mathrm{CD}^{+}$and $\mathrm{CD}^{-}$cells of the $\mathrm{CD}^{+} \mathrm{CD} 45 \mathrm{RO}^{+} \mathrm{CD} 25^{-} \mathrm{T}$ cell population did not inhibit proliferation of the autologous $\mathrm{CD}^{+}{ }_{-}$

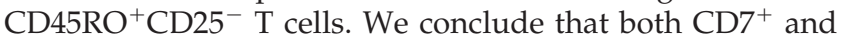
$\mathrm{CD}^{-}$cells of the $\mathrm{CD} 4^{+} \mathrm{CD} 45 \mathrm{RO}^{+} \mathrm{CD} 25^{\text {high }} \mathrm{T}$ cell population in vivo are regulatory $\mathrm{T}$ cells, $\mathrm{CD}^{-}$subset cells, however, with lower suppressor capacities.

To prove the hypothesis that $\mathrm{CD}^{-}$Treg cells in vivo may represent cells in a more advanced differentiation stage compared to the majority of $\mathrm{CD}^{+}$Treg cells, we recorded a panel of surface markers related to the late memory phenotype (Fig. 3C). KLRG-1, which is associated with late memory T cells, ${ }^{25}$ and CD57 were expressed at higher levels on CD7 ${ }^{-}$ compared to $\mathrm{CD}^{+}$Treg cells, whereas CD27 and CD28 were expressed at lower levels. Galectin-10, recently described to be upregulated in $\mathrm{CD} 4{ }^{+} \mathrm{CD} 25^{\text {high }} \mathrm{T}$ cells, ${ }^{14}$ was expressed in higher numbers, although at lower levels, in CD7 ${ }^{-}$than in $\mathrm{CD}^{+}$Treg cells. Glucocorticoid-induced tumor necrosis factor receptor (GITR), which is associated with the modulation of regulatory $\mathrm{T}$ cell function, ${ }^{26}$ was expressed in more $\mathrm{CD}^{-}$ cells than in $\mathrm{CD}^{+}$Treg cells, although at identical expression levels in both subsets. CD62L was expressed at significantly lower frequencies and at lower levels in $\mathrm{CD}^{-}$cells compared to the corresponding $\mathrm{CD}^{+}$Treg cells. The IL-7R $\alpha$ chain was expressed in nearly equal numbers of $\mathrm{CD}^{-}$and $\mathrm{CD}^{+}$Treg cells, but at slightly higher levels in $\mathrm{CD}^{+}{ }^{+} \mathrm{com}-$ pared to CD7 ${ }^{-}$Treg cells. Surface CTLA-4 expression was not detectable either on $\mathrm{CD}^{-}$or on $\mathrm{CD}^{+}$cells of the Treg cell population, whereas intracellular CTLA- 4 was expressed in nearly equal numbers of cells and in similar levels. Upon extensive amplification in vitro, $\mathrm{CD} 4^{+} \mathrm{CD} 7^{-}$Treg cells showed essentially the same phenotype as ex vivo-isolated $\mathrm{CD}^{+}{ }^{+} \mathrm{CD} 7^{-}$Treg cells (Fig. 3C). Particularly, CD4 ${ }^{+} \mathrm{CD} 7^{-}$ Treg cells expressed higher levels of KLRG-1 and lower levels of CD28, CD27, and CD62L compared to the corresponding $\mathrm{CD}^{+}$Treg cells. Taken together, reduced expression levels of CD27, CD28, and CD62L, and elevated levels of CD57 and KLRG-1 indicate $\mathrm{CD}^{-}$subset cells of $\mathrm{CD}^{+}{ }^{+} \mathrm{CD} 45 \mathrm{RO}^{+} \mathrm{CD} 25^{\text {high }}$ Treg cells as late memory Treg cells.

Therefore, we asked whether $\mathrm{CD}^{-}$Treg cells in vivo are at a more advanced proliferative stage, and therefore we monitored the relative telomere lengths of $\mathrm{CD}^{+}$and $\mathrm{CD}^{-}$ cells of the $\mathrm{CD} 4{ }^{+} \mathrm{CD} 45 \mathrm{RO}^{+} \mathrm{CD} 25^{\text {high }} \mathrm{T}$ cell population and of naïve $\mathrm{T}$ cells of the same individual by flow-FISH hybridization. Jurkat and 1301 CEM cells with known telomere lengths served as standards (Fig. 3D). As summarized in Fig. 


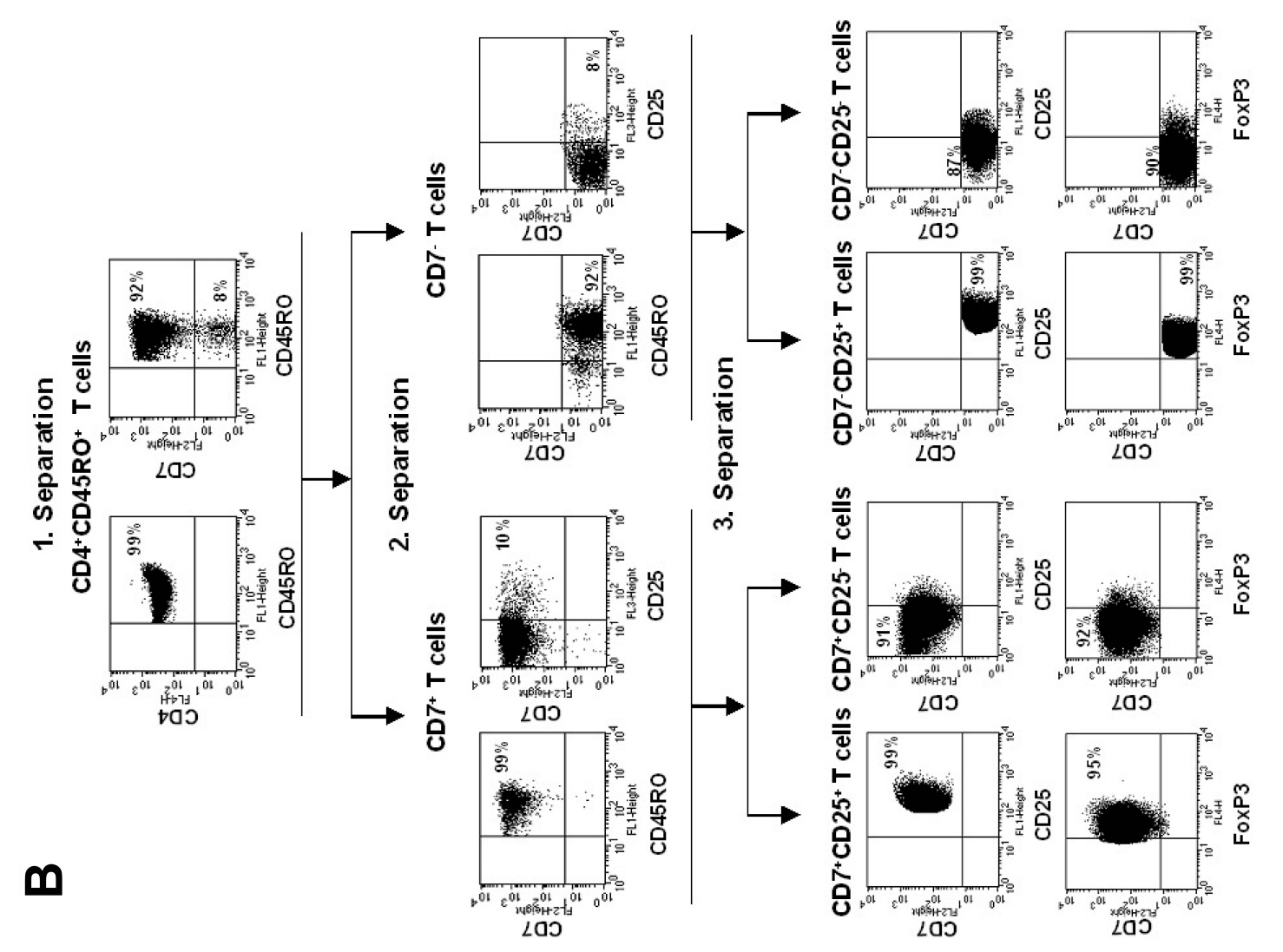

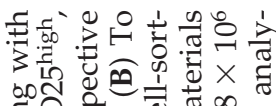

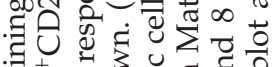
के

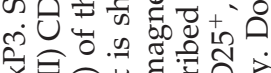

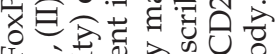

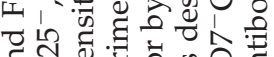
ฮิิ

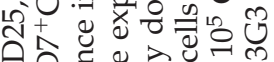
已ि记.

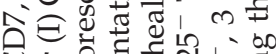

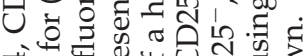

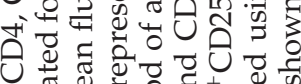
吅 है ○

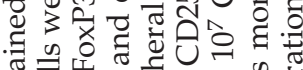
के उิ वี :0.

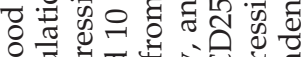

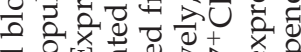

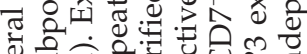

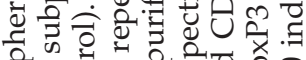
글

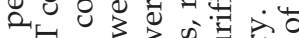

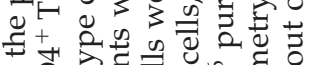

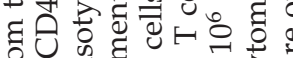
워제

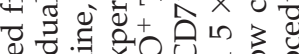

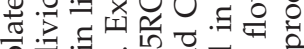

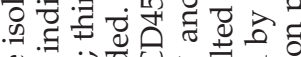
ข

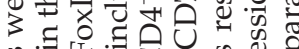

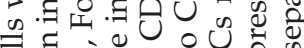

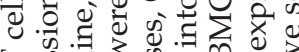
$\forall$ 远 + 0 ax丩

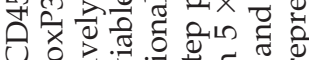
$\longrightarrow$ 三

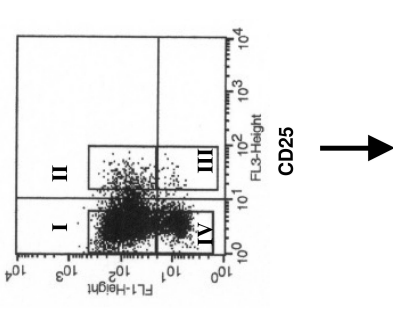

LOJ

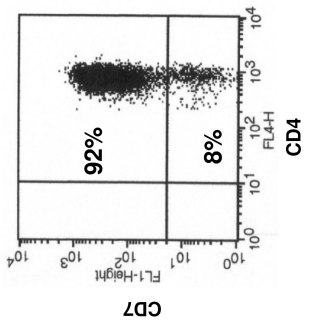

Laว

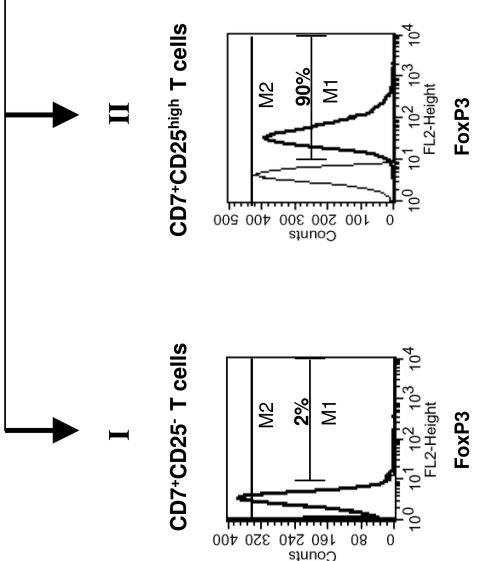

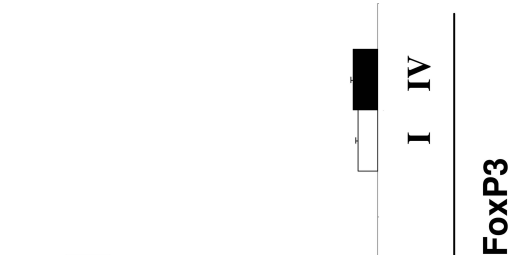

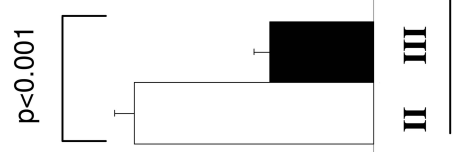

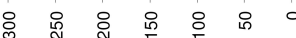

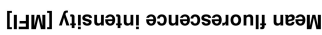
+ ठ ठ⿹

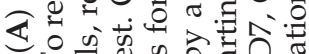

$\infty$ ต

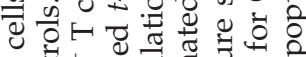

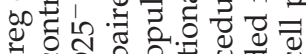
$\forall$ Uิ

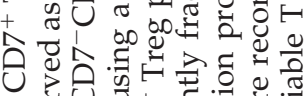
于 d

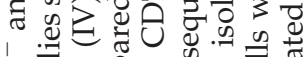

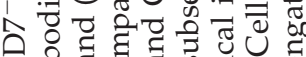
U:

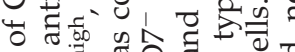

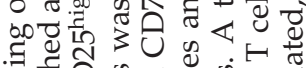

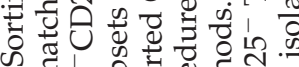
ن

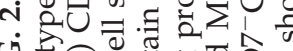

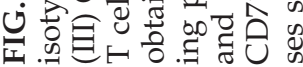




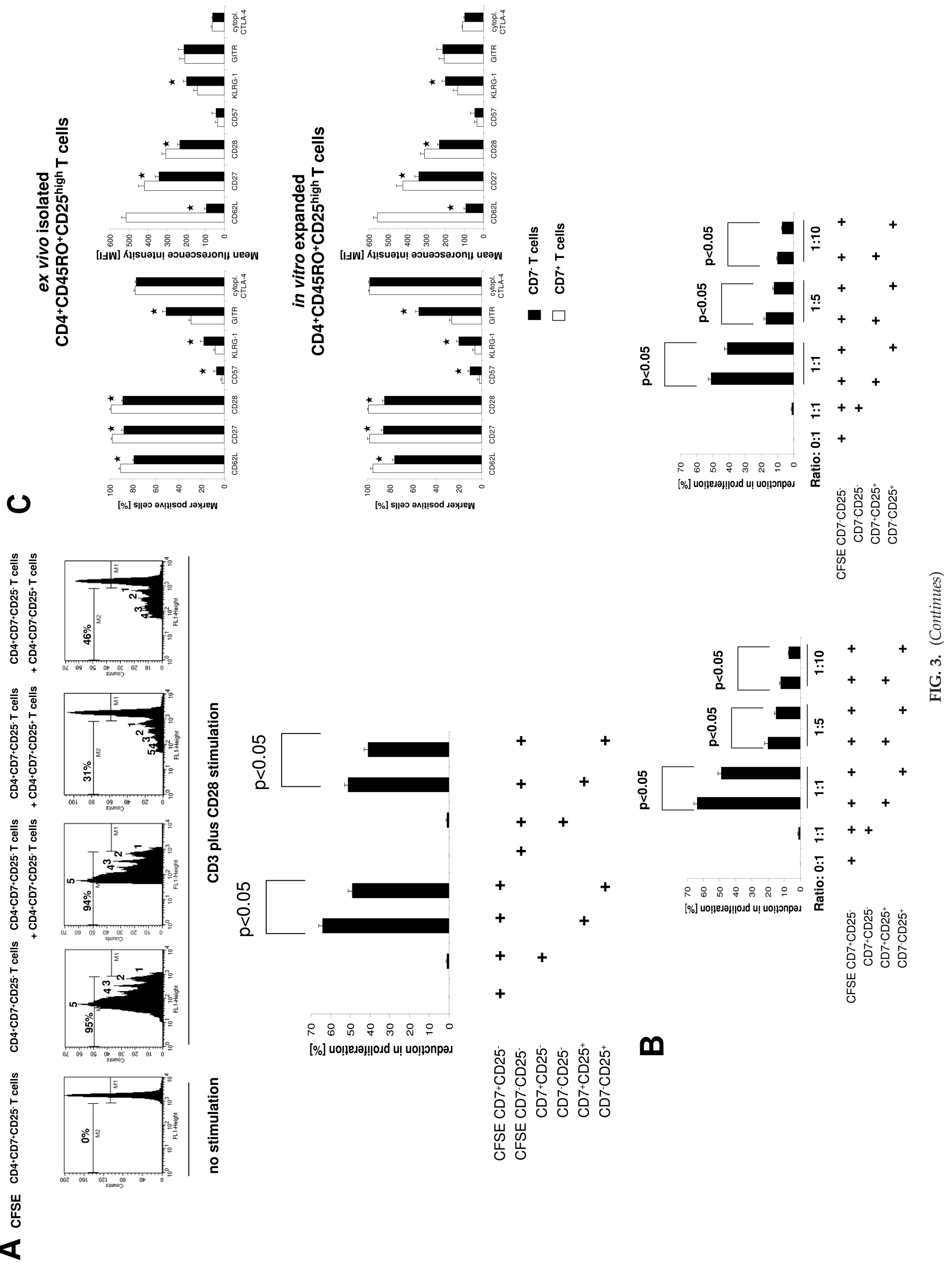




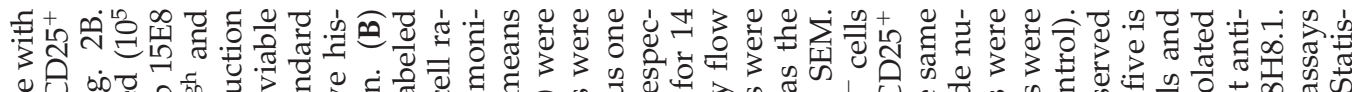

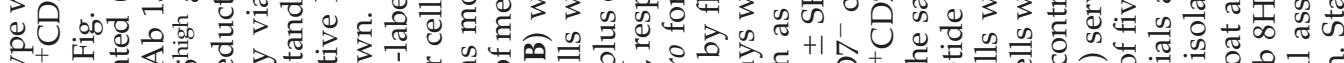

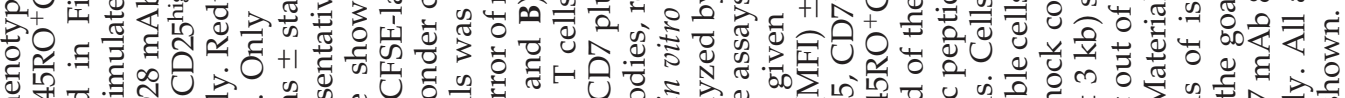

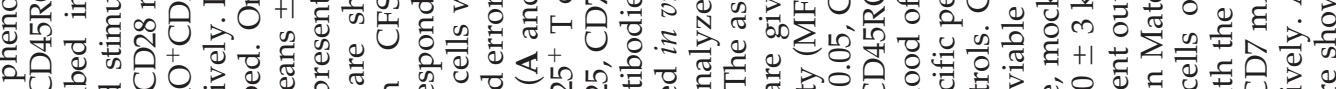

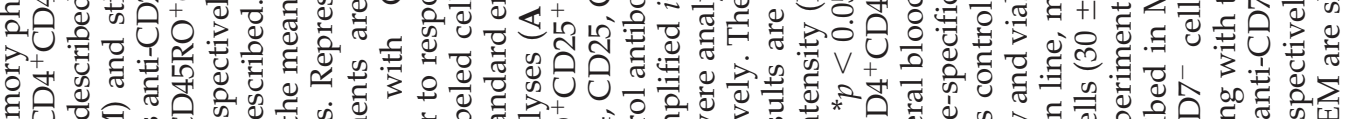

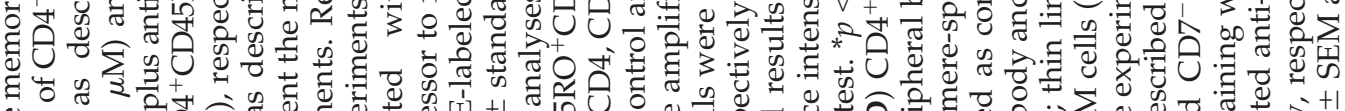

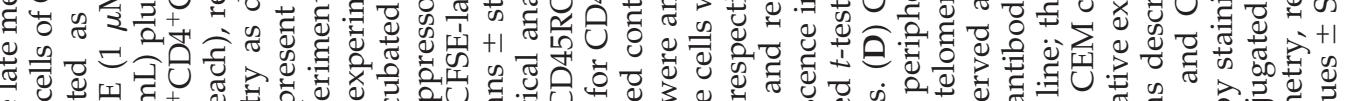

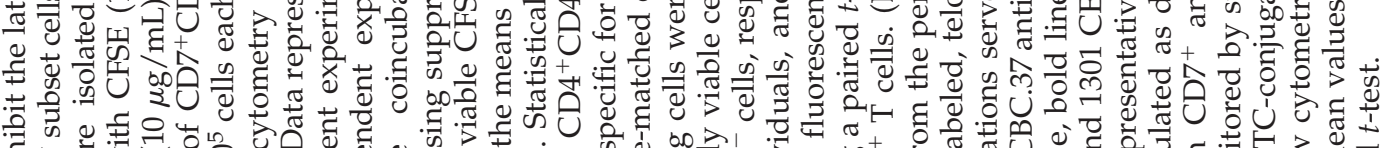

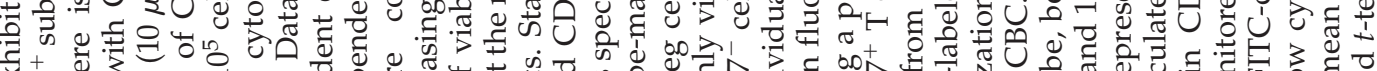

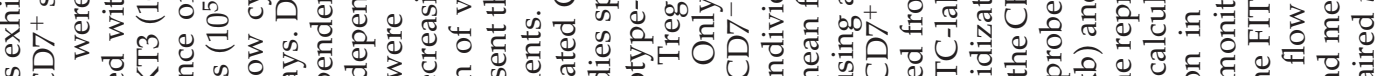

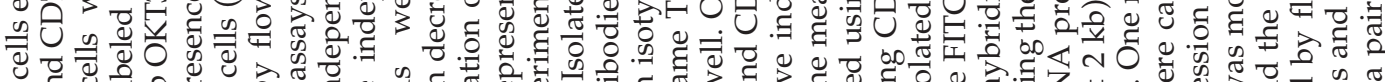

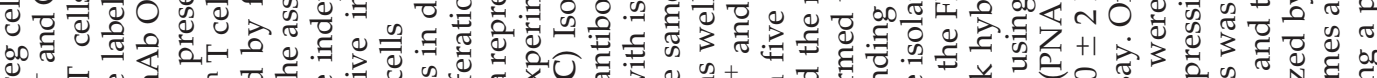

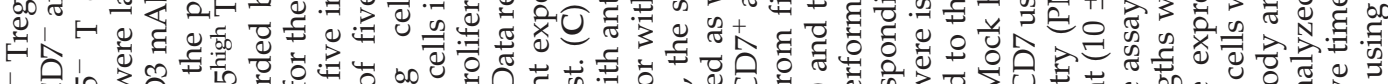

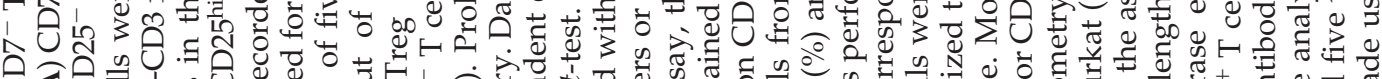

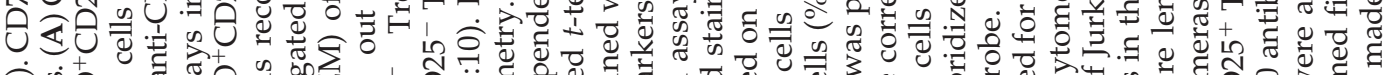

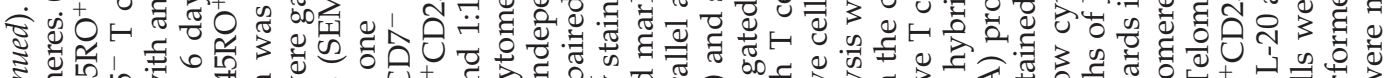

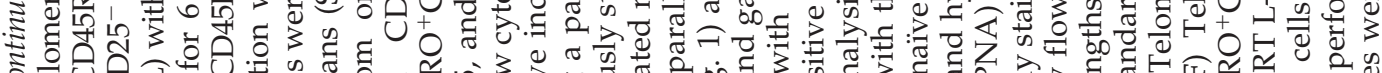

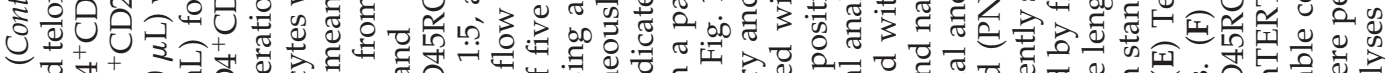
m

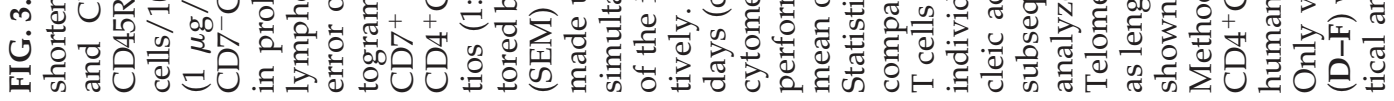

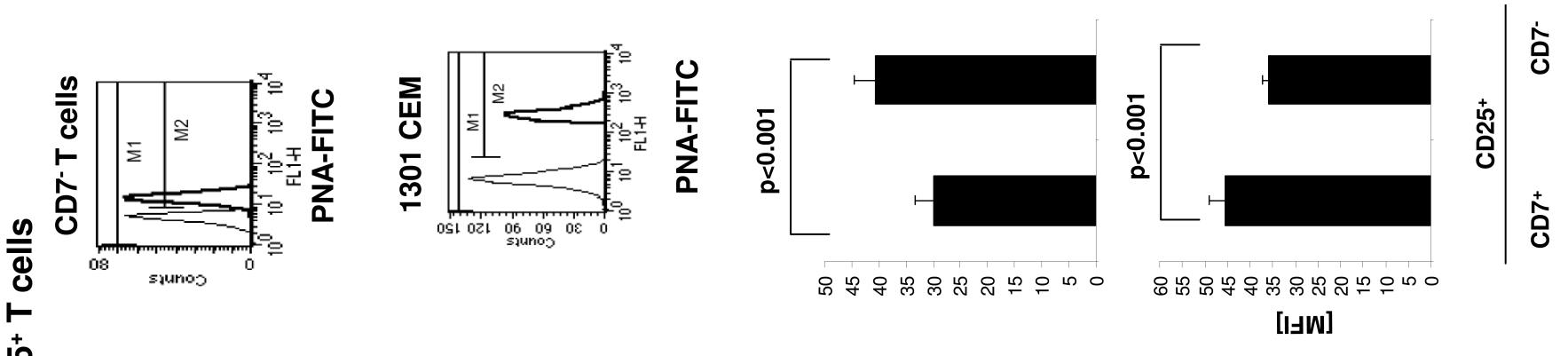

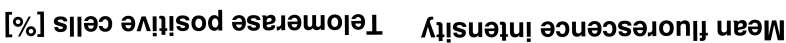
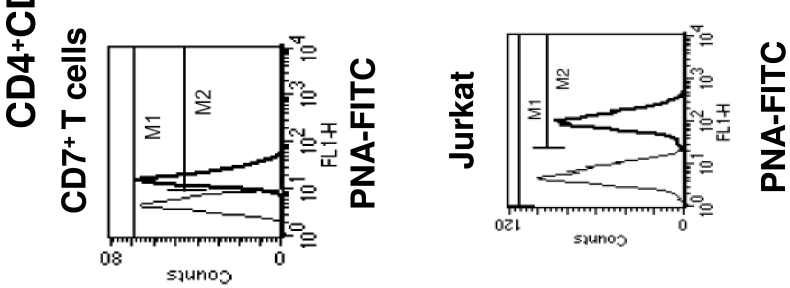

丩
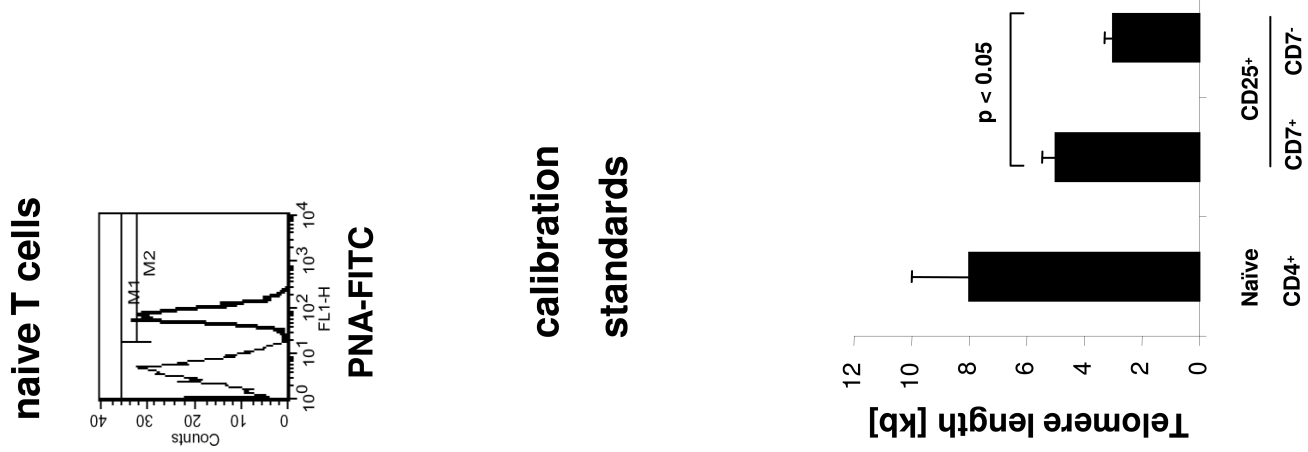

$\cong \circ \infty<+\infty$

[q⿻्र] чұбиә әдәшоㅋ 


\section{嘉斏

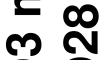

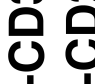 \\ 敦}

,

$\frac{0}{3}$

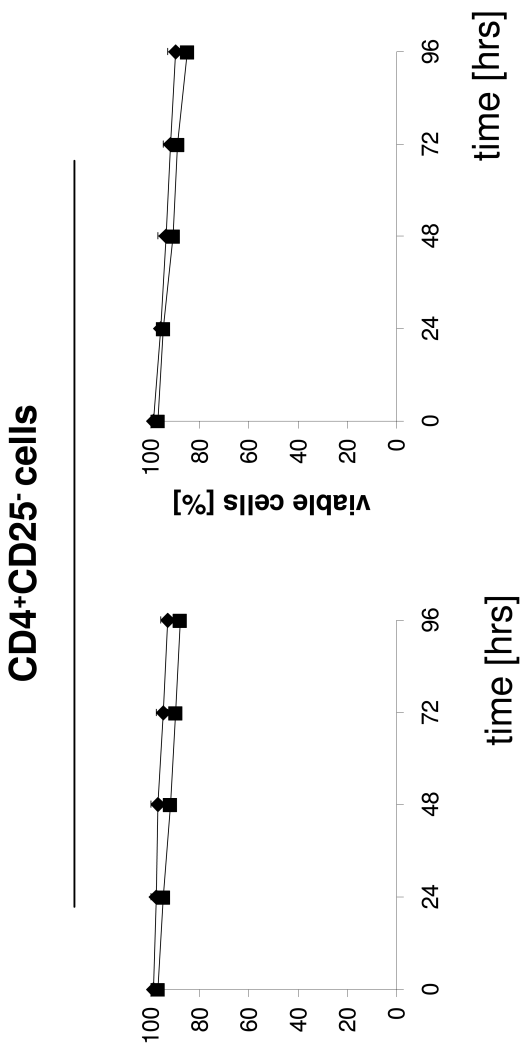

[\%] s॥ə0 ә|qе!

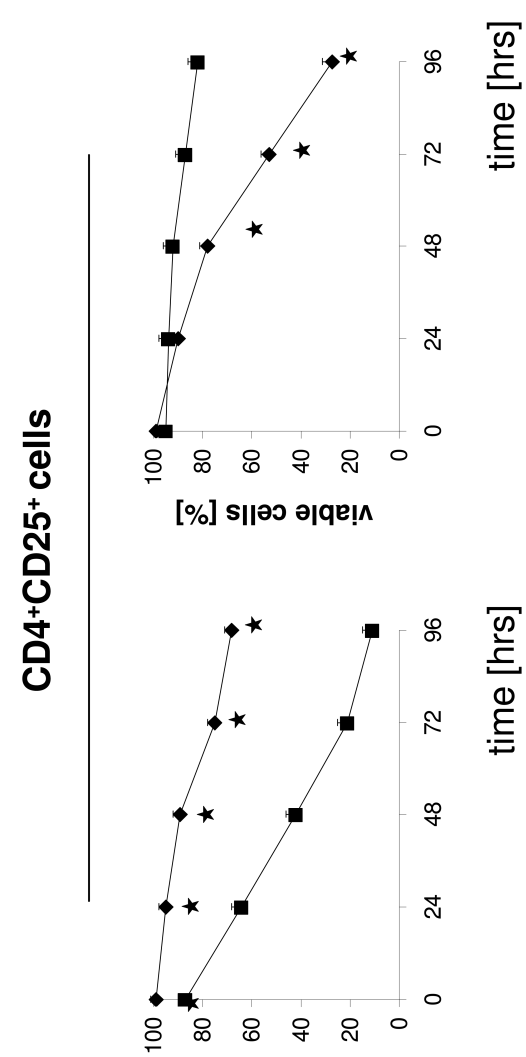

[\%] s||әэ ә|qе!^

0

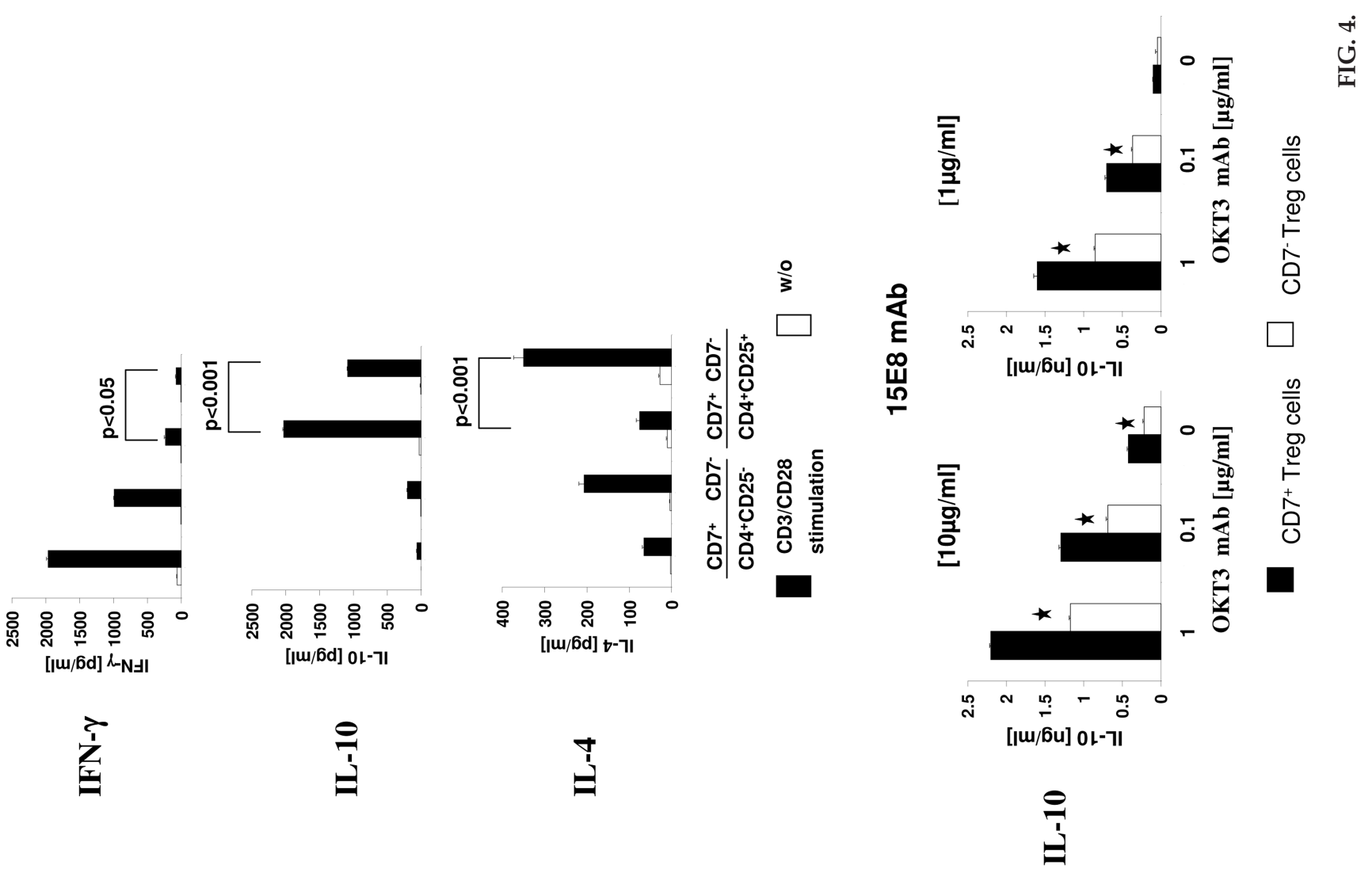



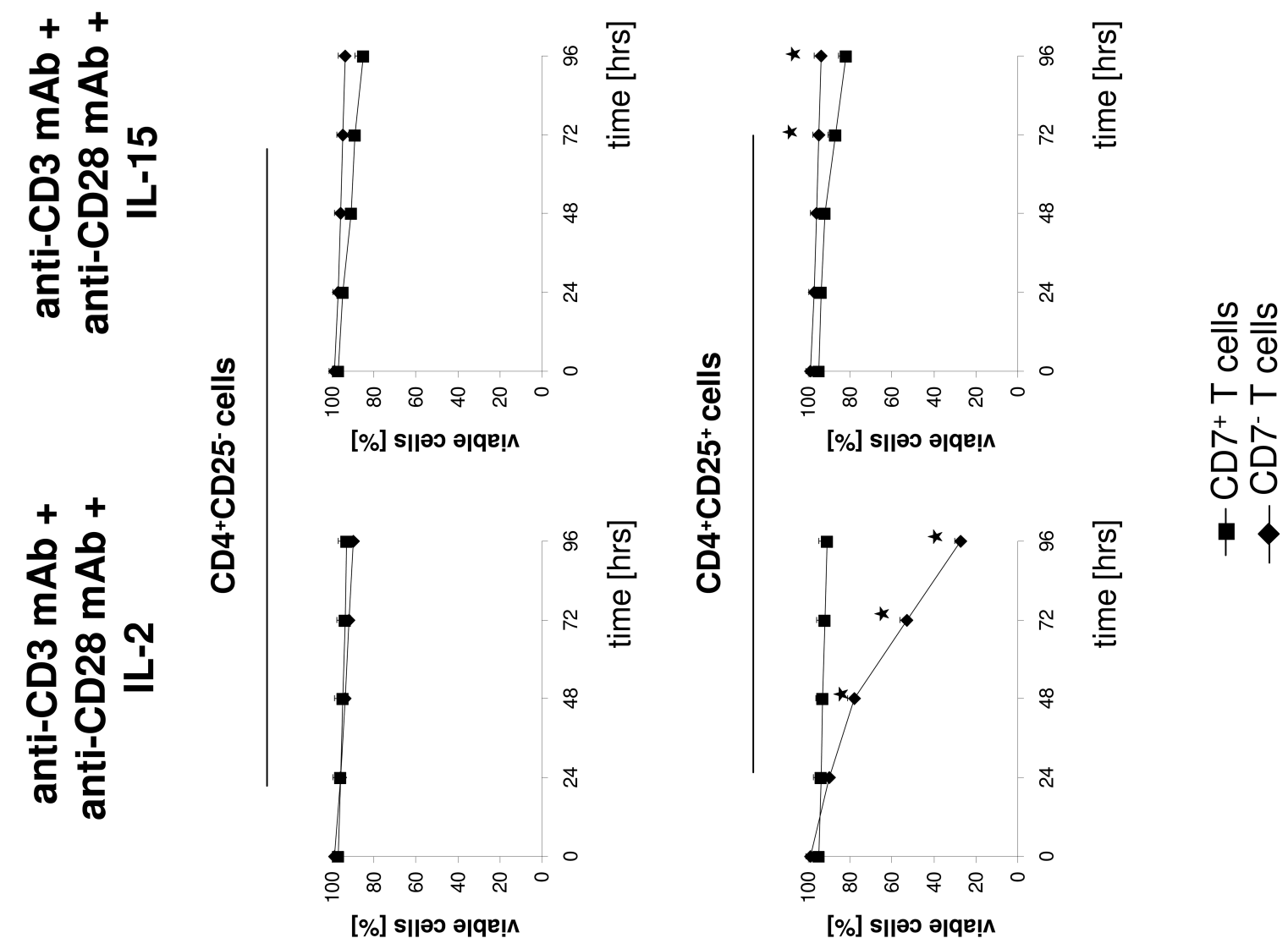

U
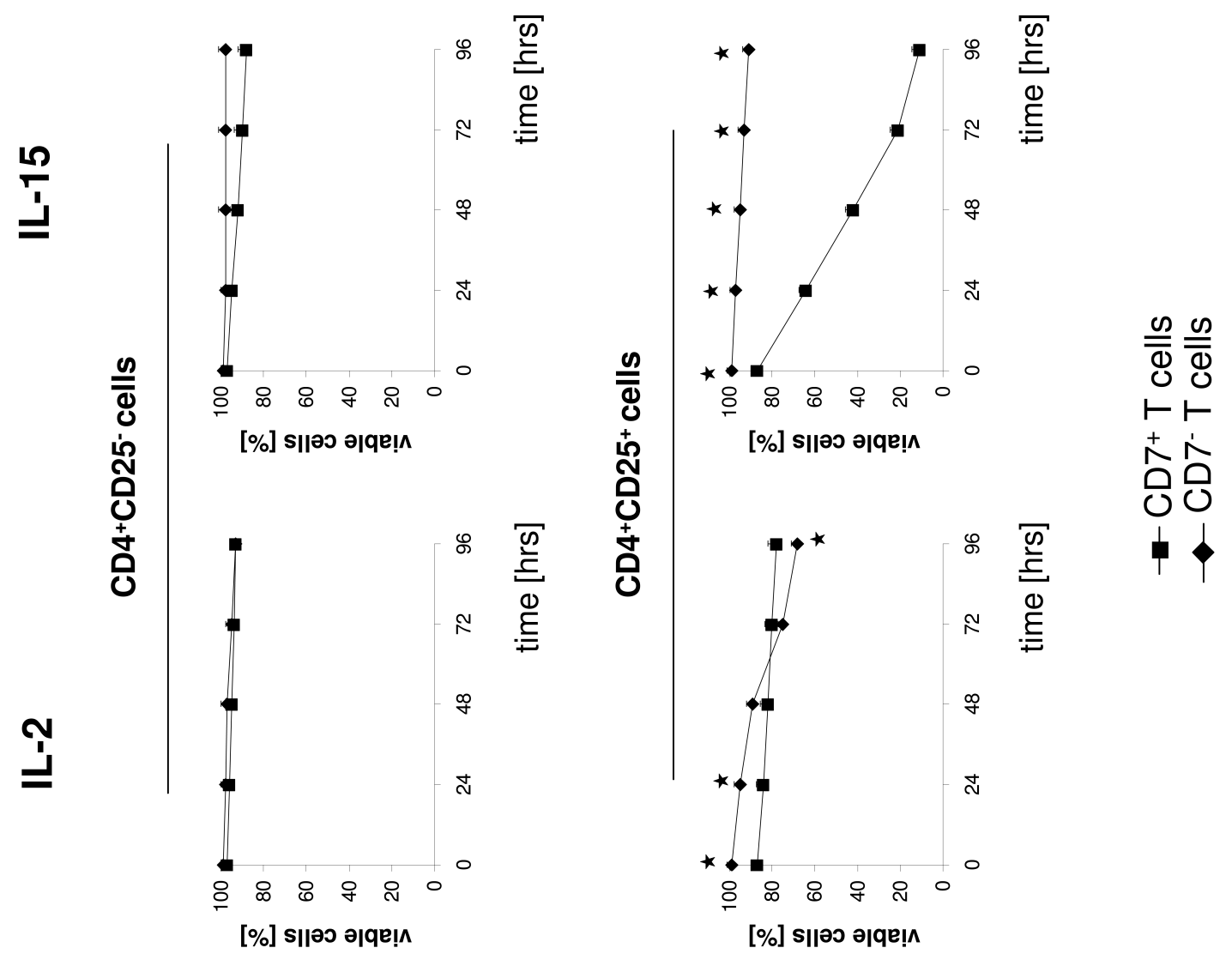

อ 

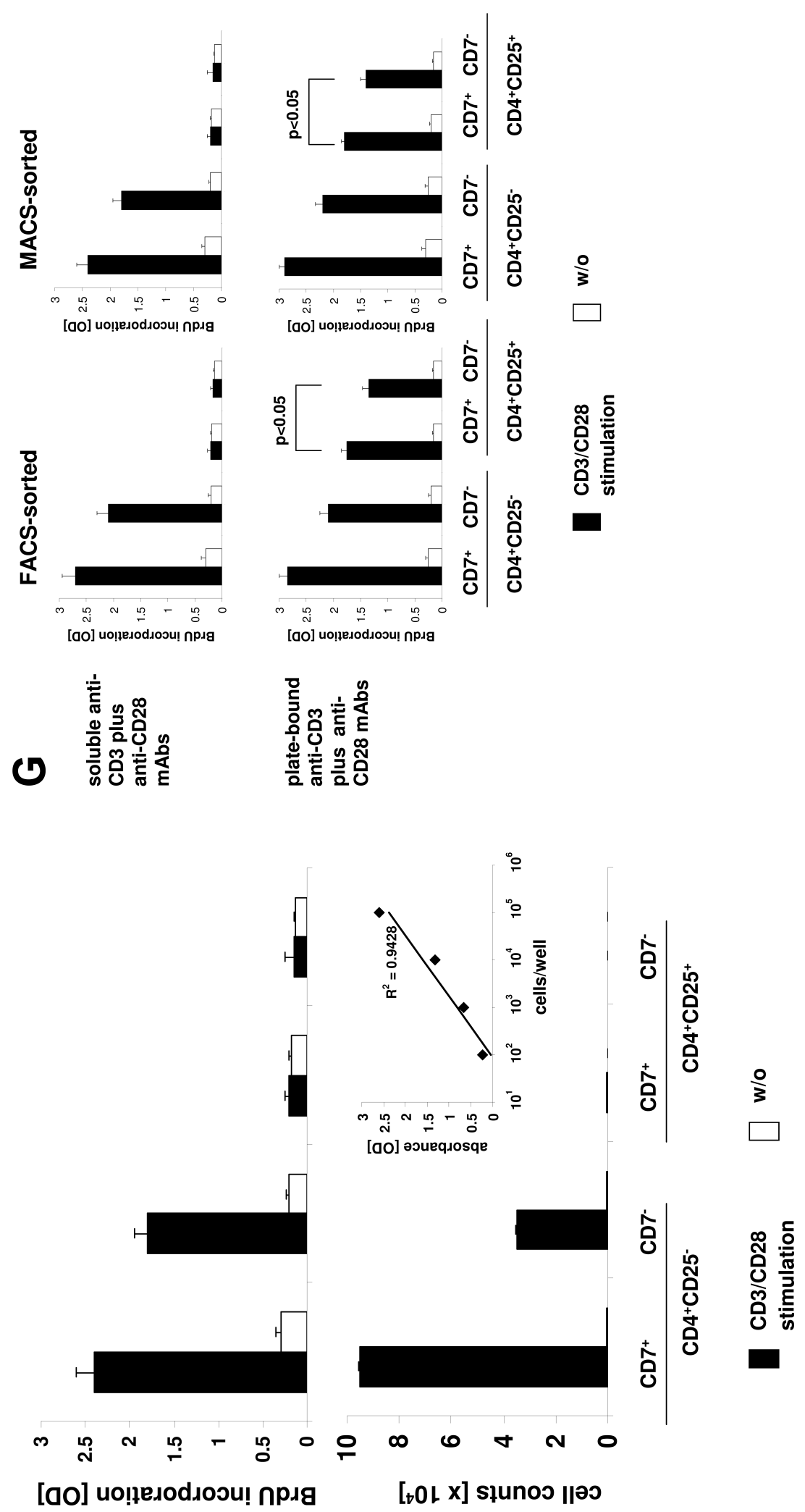

u.

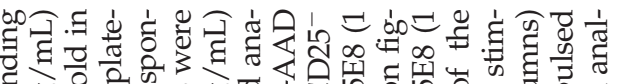

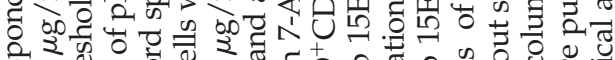

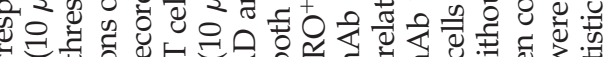
o m

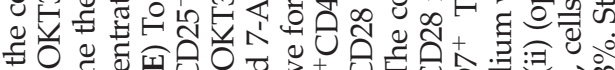
-

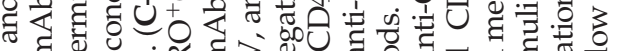

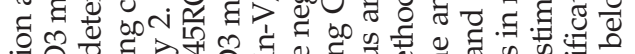

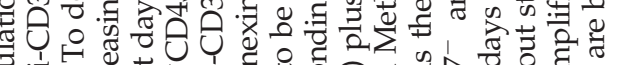

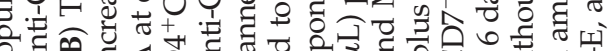
2. 寸).

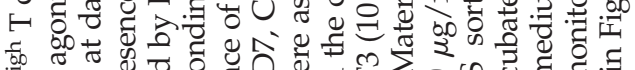

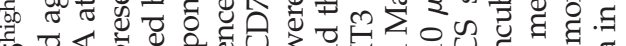

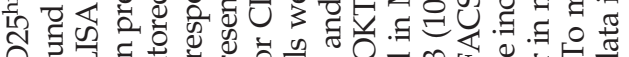

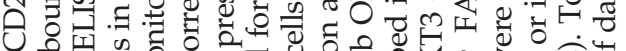

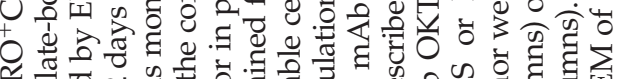

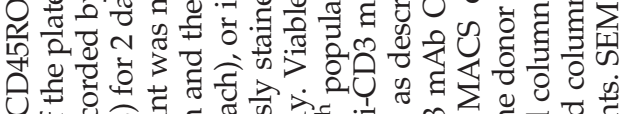
+

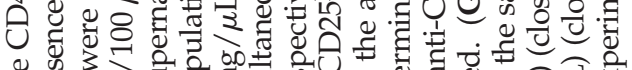
乎边 药

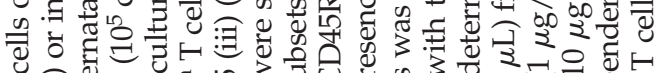

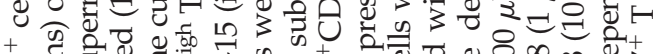

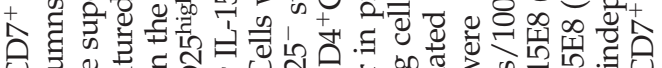

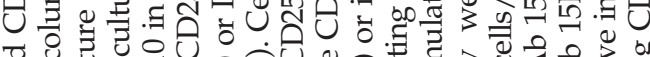
눙

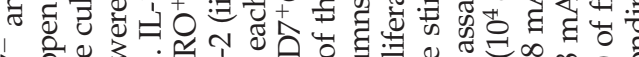
مि Oे..

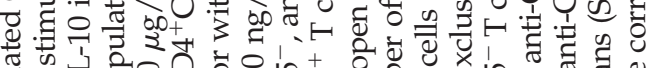

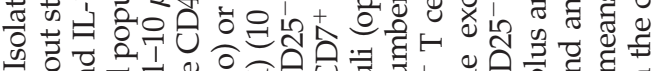

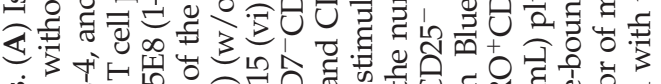

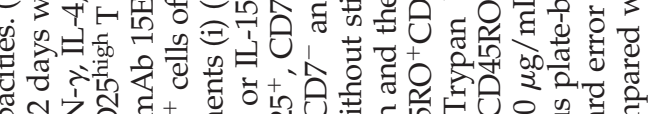

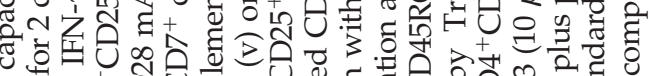

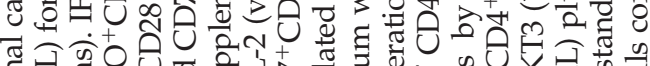

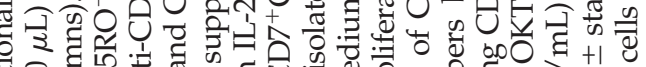

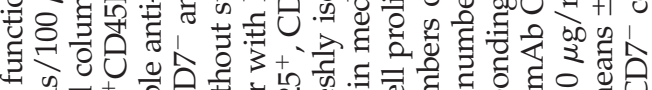

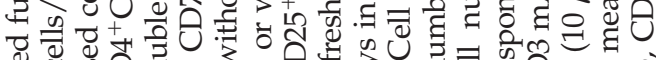

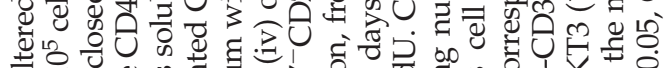

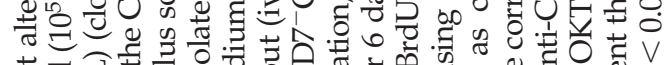

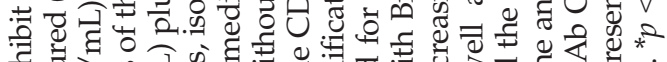

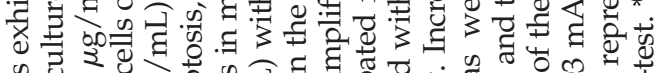

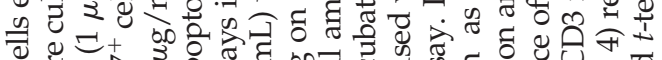

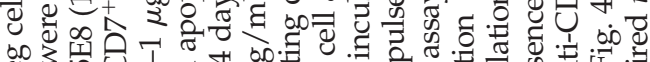

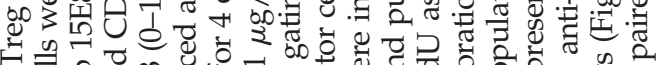

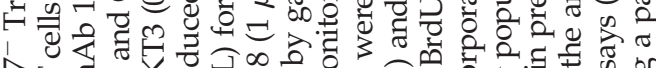
人 ن.

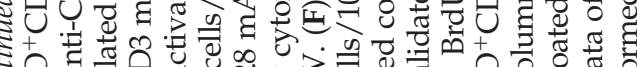

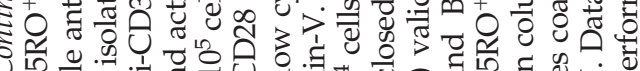

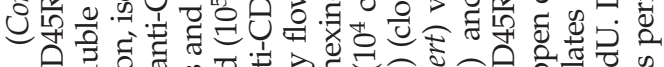

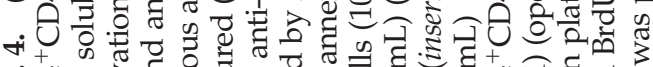

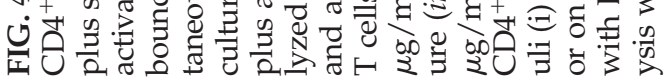


$3 \mathrm{E}$, the mean telomere length of $\mathrm{CD}^{-}$Treg cells in the peripheral blood was significantly shorter than that of the corresponding $\mathrm{CD}^{+}$Treg cells, indicating that $\mathrm{CD}^{-}$Treg cells are obviously in a more advanced proliferative stage than $\mathrm{CD}^{+}$Treg cells. This conclusion is in accordance to our observation that prolonged propagation in vitro generates $\mathrm{CD}^{-}$Treg cells. For comparison, naïve $\mathrm{T}$ cells had longer telomeres than $\mathrm{CD}^{+}{ }^{+} \mathrm{CD} 25^{+}$Treg cells, as previously described. ${ }^{27}$ An increased number of $\mathrm{CD}^{-}$Treg cells expressed telomerase compared to $\mathrm{CD}^{+}$Treg cells, whereas the amount of telomerase per cell was significantly decreased in $\mathrm{CD}^{-}$Treg cells (Fig. 3F).

\section{CD7- Treg cells exhibit altered effector functions}

We monitored the cytokines secreted by isolated CD7 ${ }^{-}$ and $\mathrm{CD}^{+}$cells of the $\mathrm{CD} 4{ }^{+} \mathrm{CD} 45 \mathrm{RO}^{+} \mathrm{CD} 25^{+}$Treg cell population upon $\mathrm{CD} 3 / \mathrm{CD} 28$ engagement. As summarized in Fig. 4A, IL-10 secretion was induced in both $\mathrm{CD}^{-}$and $\mathrm{CD}^{+}$ Treg cells upon stimulation; the levels of secreted IL-10, however, were significantly lower in $\mathrm{CD}^{-}$compared to $\mathrm{CD}^{+}$ Treg cells. For comparison, IL-10 was detectable only in background levels in cultures of the corresponding $\mathrm{CD}^{+}{ }^{+} \mathrm{CD} 45 \mathrm{RO}^{+} \mathrm{CD} 25^{-} \mathrm{T}$ cells. In contrast, IFN- $\gamma$ secretion was very poorly induced in cells of both $\mathrm{CD}^{+}$and $\mathrm{CD}^{-}$ Treg cells, but was induced efficiently in the corresponding cells of the $\mathrm{CD}^{+}{ }^{+} \mathrm{CD} 45 \mathrm{RO}^{+} \mathrm{CD} 25^{-} \mathrm{T}$ cell population. Notably, IL-4 was highly expressed by CD7 ${ }^{-}$Treg cells upon CD3/CD28 stimulation compared to $\mathrm{CD}^{+}$Treg cells. Flow cytometric analyses confirmed that significantly higher numbers of $\mathrm{CD}^{-}$Treg cells $(14 \pm 2 \%)$ produce IL- 4 compared to $\mathrm{CD}^{+}$Treg cells $(1 \pm 1 \%)$. No secreted TGF- $\beta 1$ was detected in cell culture supernatants of $\mathrm{CD}^{+}$and $\mathrm{CD}^{-}$Treg cells by ELISA nor did we detect the membrane-bound form of TGF$\beta 1$ by flow cytometric analyses. For comparison, no IL-2 was detected in $\mathrm{CD}^{+}$or $\mathrm{CD}^{-}$Treg cells, but in the corresponding $\mathrm{CD} 4^{+} \mathrm{CD} 25^{\text {low }} \mathrm{T}$ cells.
To monitor the activation threshold of $\mathrm{CD}^{+}$and $\mathrm{CD}^{-}$ Treg cells, we incubated the respective Treg cells in a crosstitration setting with increasing amounts of the agonistic anti-CD3 and anti-CD28 antibodies and recorded IL-10 secretion. As summarized in Fig. 4B, the amount of stimuli required to induce the same amount of secreted IL-10 was approximately $10-$ fold higher in $\mathrm{CD}^{-}$than in $\mathrm{CD}^{+}$Treg cells, indicating that $\mathrm{CD}^{-}$Treg cells exhibit an increased activation threshold compared to $\mathrm{CD}^{+}$Treg cells.

Without antigenic stimulation, the majority of $\mathrm{CD} 4{ }^{+} \mathrm{CD} 25^{\text {high }} \mathrm{T}$ cells rapidly enter apoptosis in vitro. ${ }^{28}$ Here we assessed the frequency of apoptotic cells of freshly isolated $\mathrm{CD}^{-}$and $\mathrm{CD}^{+}$Treg cells upon CD3/CD28 stimulation in vitro. As summarized in Fig. $4 \mathrm{C}, \mathrm{CD}^{-}$Treg cells are more resistant to spontaneous apoptosis in vitro than $\mathrm{CD}^{+}$Treg cells. Upon CD3/CD28 stimulation, however, CD7 ${ }^{-}$Treg cells rapidly enter apoptosis, whereas $\mathrm{CD}^{+}$Treg cells are rescued from apoptosis. Addition of IL-2 poorly, but of IL-15 more effectively prevented apoptosis of $\mathrm{CD}^{-}$Treg cells compared to incubation without cytokines (Fig. 4D,E). CD7 ${ }^{+}$Treg cells, in contrast, were rescued by IL-2 from apoptosis, whereas IL-15 had no significant effect. $\mathrm{CD}^{-}$Treg cells obviously require IL15 and $\mathrm{CD}^{+}$Treg cells IL-2 for survival.

Both $\mathrm{CD}^{-}$and $\mathrm{CD}^{+}$Treg cells exhibited no significant proliferative capacities in presence of agonistic anti-CD3 plus anti-CD28 antibodies (Fig. 4F,G), but proliferation of both Treg cell subsets was induced by immobilized stimuli as recorded by BrdU-incorporation (Fig. 4G). For comparison, the corresponding cells of the $\mathrm{CD} 4{ }^{+} \mathrm{CD} 45 \mathrm{RO}^{+} \mathrm{CD} 25^{-} \mathrm{T}$ cell population are induced to proliferate under both conditions. Essentially the same results were obtained with MACS- and FACS-sorted cells from the same donor (Fig. 4G). Treg cells of both $\mathrm{CD}^{-}$and $\mathrm{CD}^{+}$subtypes obviously require strong TCR/CD3 and CD28 engagement to initiate their amplification. CD7 ${ }^{-}$Treg cells, however, exhibited significantly lower proliferation capacities under identical conditions than the corresponding $\mathrm{CD}^{+}$Treg cells.

TAble 1. Expression of Homing Receptors on Ex VIVO-IsOlAted AND IN VITRO-ExPANDED $\mathrm{CD}^{-}{ }^{-}$AND $\mathrm{CD} 7^{+}$Cells of CD4 ${ }^{+} \mathrm{CD} 25^{\text {high }} \mathrm{T}$ CELLS

\begin{tabular}{|c|c|c|c|c|c|c|c|c|}
\hline & \multicolumn{4}{|c|}{$\begin{array}{c}\text { Ex vivo-isolated } \\
C D 4^{+} C D 25^{\text {high }} T \text { cells }\end{array}$} & \multicolumn{4}{|c|}{$\begin{array}{c}\text { In vitro-expanded } \\
C D 4^{+} C D 25^{\text {high }} T \text { cells }\end{array}$} \\
\hline & \multicolumn{2}{|c|}{$\mathrm{CD7}^{-}$} & \multicolumn{2}{|c|}{$\mathrm{CD}^{+}$} & \multicolumn{2}{|c|}{$\mathrm{CD}^{-}$} & \multicolumn{2}{|c|}{$\mathrm{CD7}^{+}$} \\
\hline & {$[\%]$} & $M F I$ & {$[\%]$} & $M F I$ & {$[\%]$} & $M F I$ & {$[\%]$} & $M F I$ \\
\hline Integrin $\alpha 4 \beta 1$ & $92 \pm 1$ & $236 \pm 20$ & $69 \pm 2$ & $177 \pm 12$ & $95 \pm 2$ & $240 \pm 18$ & $66 \pm 3$ & $172 \pm 11$ \\
\hline Integrin $\alpha 4 \beta 7$ & $29 \pm 3$ & $232 \pm 9$ & $31 \pm 2$ & $209 \pm 10$ & $28 \pm 2$ & $229 \pm 8$ & $33 \pm 3$ & $206 \pm 11$ \\
\hline CD103 & $<1$ & N.D. & $6 \pm 1$ & $98 \pm 5$ & $<1$ & N.D. & $8 \pm 2$ & $100 \pm 6$ \\
\hline CCR4 & $97 \pm 2$ & $195 \pm 8$ & $77 \pm 3$ & $168 \pm 9$ & $98 \pm 1$ & $191 \pm 7$ & $74 \pm 3$ & $161 \pm 8$ \\
\hline CCR7 & $15 \pm 1$ & $160 \pm 13$ & $41 \pm 2$ & $201 \pm 18$ & $12 \pm 2$ & $155 \pm 12$ & $45 \pm 2$ & $210 \pm 19$ \\
\hline CCR10 & $20 \pm 1$ & $181 \pm 2$ & $4 \pm 2$ & $65 \pm 3$ & $22 \pm 2$ & $188 \pm 3$ & $6 \pm 3$ & $68 \pm 4$ \\
\hline CLA & $43 \pm 4$ & $222 \pm 13$ & $17 \pm 5$ & $187 \pm 15$ & $41 \pm 2$ & $234 \pm 15$ & $15 \pm 2$ & $195 \pm 11$ \\
\hline CD31 & $3 \pm 3$ & $16 \pm 4$ & $20 \pm 5$ & $23 \pm 8$ & $5 \pm 2$ & $18 \pm 6$ & $22 \pm 3$ & $26 \pm 6$ \\
\hline
\end{tabular}

$\mathrm{CD} 4{ }^{+} \mathrm{CD} 25^{\text {high }} \mathrm{T}$ cells were isolated from the peripheral blood of 5 healthy donors or from in vitro simulation assays at day 14 (cf. Fig. 1 ). Cells were stained with antibodies specific for CD7 and for the indicated markers. Isotype-matched antibodies served as controls. Cells were analyzed by flow cytometry and gated on $\mathrm{CD}^{+}$and $\mathrm{CD}^{-}$cells, respectively. Data are given as the mean of positive cells [\%] and the mean fluorescence intensity (MFI) \pm SEM of five independent experiments.

Note: MFI, mean fluorescence intensity; N.D., not determined. 


\section{A}

CD4+FoxP3 ${ }^{+} \mathrm{T}$ cells $[\%]$

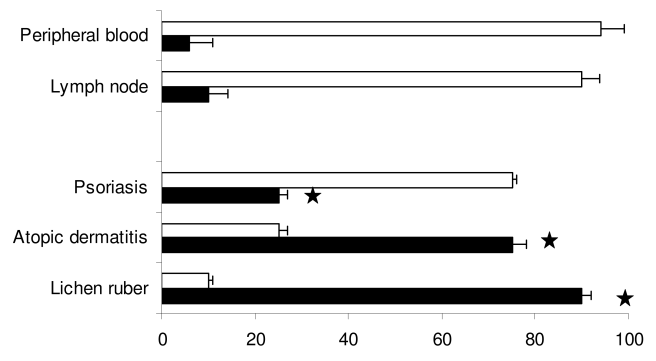

CD7+ $7^{+}$reg cells
$\mathrm{CD} 4{ }^{+} \mathrm{CD} 25^{+} \mathrm{T}$ cells $[\%]$

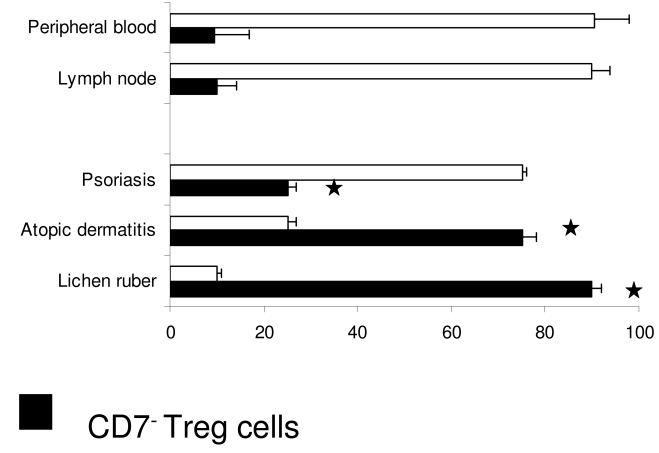

B

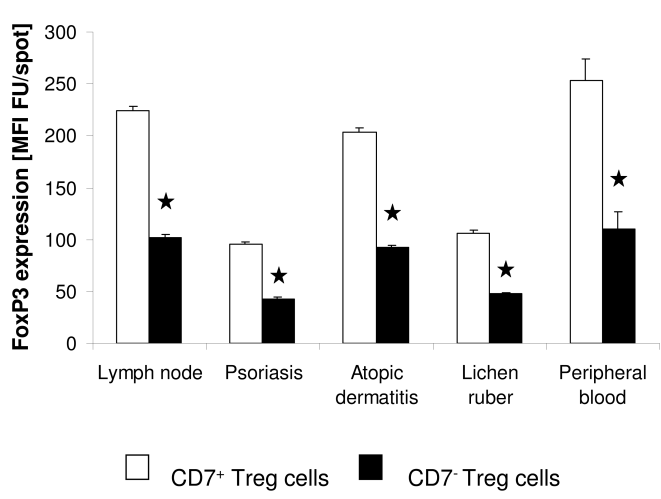

FIG. 5. $\mathrm{CD}^{-}$Treg cells accumulate in inflammatory lesions in the periphery. (A) Serial sections of biopsies from reactive lymph node, psoriasis, atopic dermatitis, and lichen ruber were stained simultaneously for: (i) CD4, CD7, FoxP3; (ii) CD4, CD7, CD25; (iii) CD4, CD25, FoxP3; and (iv) CD4, CD127, FoxP3, respectively. Sections were analyzed by laser-scan microscopy as described in Materials and Methods. Specificity of cell staining was assayed by incubation of the slides with the respective isotype-matched control antibodies. The numbers of $\mathrm{CD}^{+}$cells (open bars) and $\mathrm{CD}^{-}$cells (closed bars) with $\mathrm{CD} 4{ }^{+} \mathrm{FoxP}^{+}$and with $\mathrm{CD} 4{ }^{+} \mathrm{CD} 25^{+}$phenotypes, respectively, were determined. (B) For quantitative recording of FoxP3-specific Cy5 fluorescence signals, regions of interest were gated on Cy5 spots and the mean fluorescence intensity (FU, fluorescence unit) per spot (MFI/spot) was determined using the ImageJ software (U.S. National Institutes of Health). A minimum of 100 cells of each cell population in each biopsy section was recorded. Data represent the mean \pm SEM. ${ }^{*} p<$ 0.05, $\mathrm{CD}^{-}$cells compared with the corresponding $\mathrm{CD}^{+} \mathrm{T}$ cells. (C and D) Laser scan micrographs of immunofluorescence analyses of a lichen ruber and reactive lymph node biopsy are shown. (Circles) $\mathrm{CD}^{-} \mathrm{CD} 4^{+} \mathrm{T}$ cells; (squares) $\mathrm{CD} 7^{+} \mathrm{CD} 4^{+}$ T cells. Note that nearly all FoxP3 ${ }^{+}$cells coexpress CD4 and CD25, but have downregulated CD127 (IL-7R $\alpha$ ) expression. Magnification, 630×. (HE) overview of the biopsy section upon hematoxylin eosin stain. (E) Serial biopsy sections of the psoriasis lesion were hybridized with a telomere-specific PNA probe, followed by staining for CD4 and CD7 and for FoxP3 and CD7, respectively. (Circles) $\mathrm{CD}^{-}$; (squares) $\mathrm{CD}^{+} \mathrm{T}$ cells. Magnification, $630 \times$. For quantitative recording of telomerespecific Cy3 fluorescence signals, regions of interest were gated on $\mathrm{Cy} 3$ spots of the $\mathrm{CD} 7^{-} \mathrm{FoxP}^{+}$and $\mathrm{CD}^{+} \mathrm{FoxP}^{+} \mathrm{cells}$, respectively, and the mean fluorescence intensity per spot (MFI/spot) was determined using the ImageJ software (U.S. National Institutes of Health). MFI per telomere spot directly correlates with the mean telomeric restriction fragment length as recorded by Southern blot hybridization. ${ }^{22}$ A minimum of 100 cells of each cell population in each biopsy section was recorded. Data represent the mean \pm SEM. Statistical analyses (Fig. 5) were performed using a paired $t$-test test. (FU) fluorescence unit. (Continues $\longrightarrow$ ) 


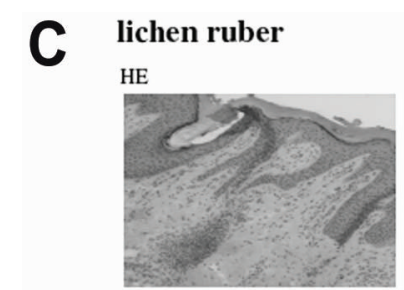

CD7

CD4

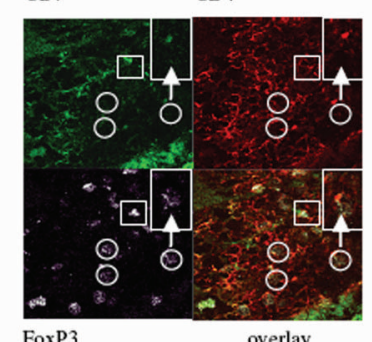

CD7 isotype control CD4 isotype control

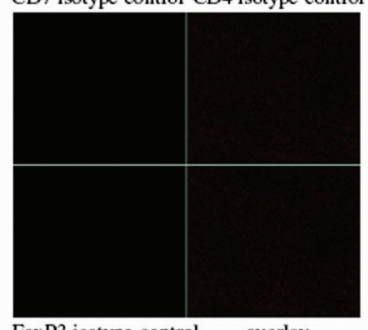

FoxP3 isotype control overlay

Lymph node

HE

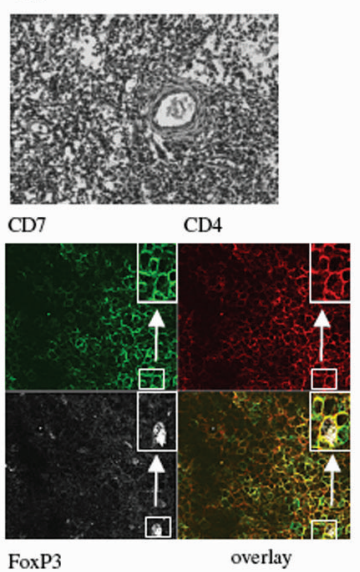

FoxP3

overlay

CD7 isotype control CD4 isotype control

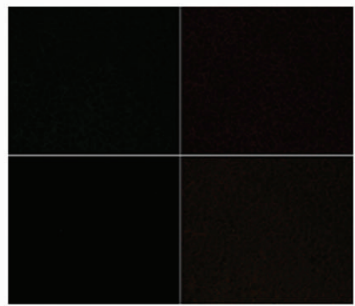

FoxP3 isotype control

overlay

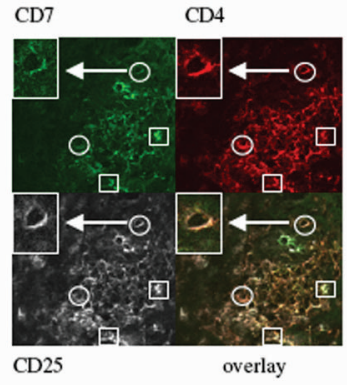

$\mathrm{CD} 25$

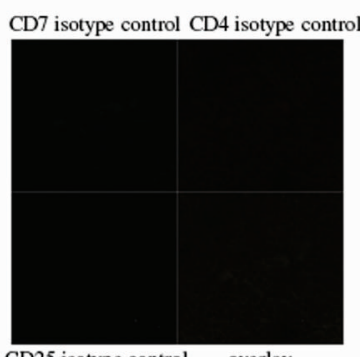

CD25 isotype control overlay

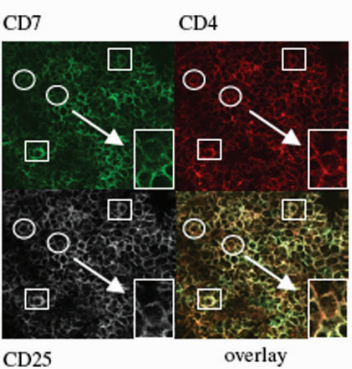

CD7 isotype control CD4 isotype control

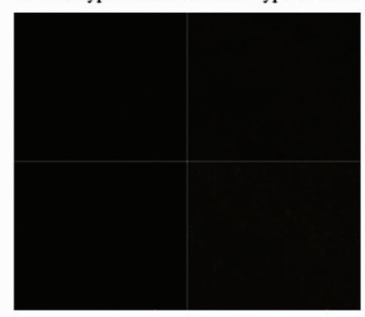

CD25 isotype control
C lichen ruber

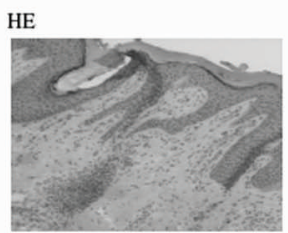

CD4

CD25

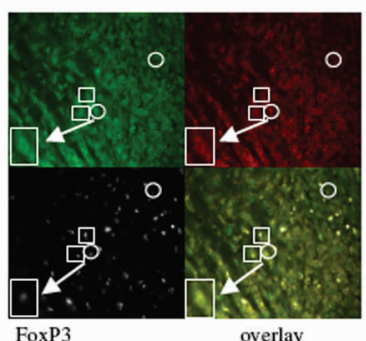

FoxP3

control

CD25 isotype control

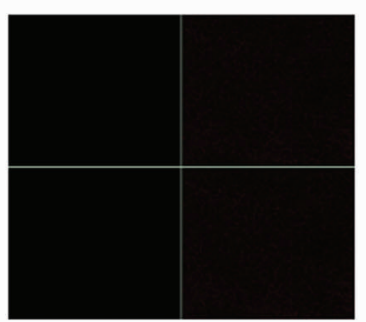

FoxP3 isotype

control

overlay

Lymph node

HE
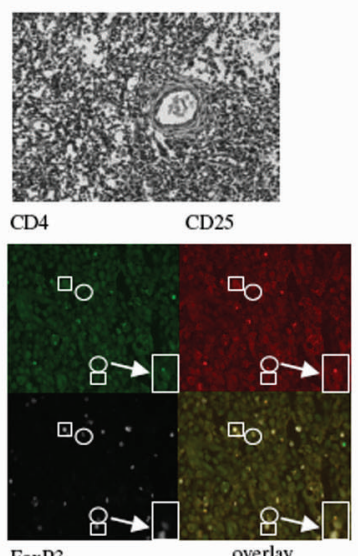

FoxP3

D25 isotype

CD4 isotype

control

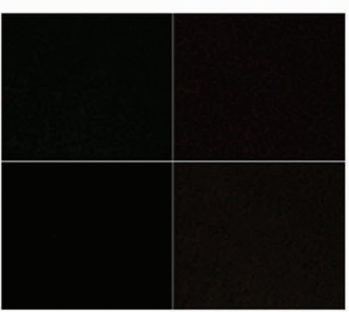

FoxP3 isotype

overlay

control
CD4

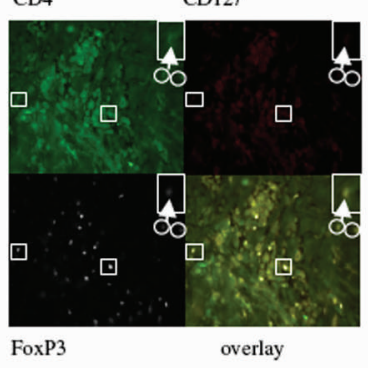

CD4 isotype CD127 isotype control control

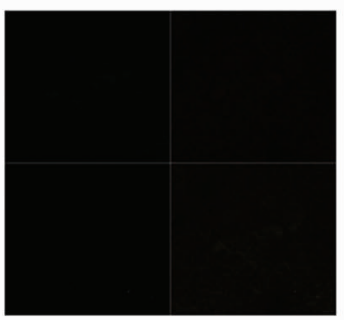

FoxP3 isotype control

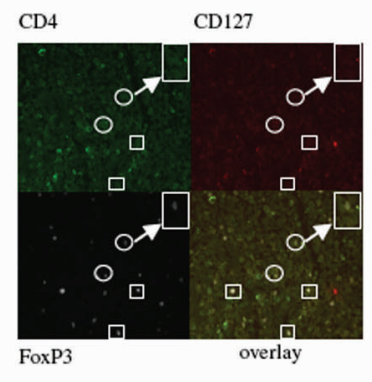

CD4 isotype $\quad \mathrm{CD} 127$ isotype control control

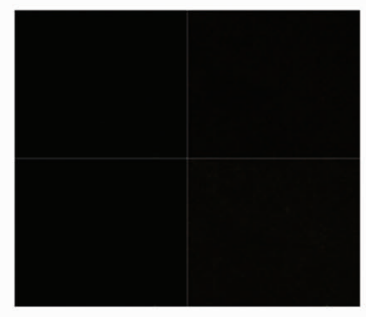

FoxP3 isotype overlay control

FIG. 5. (Continued). 


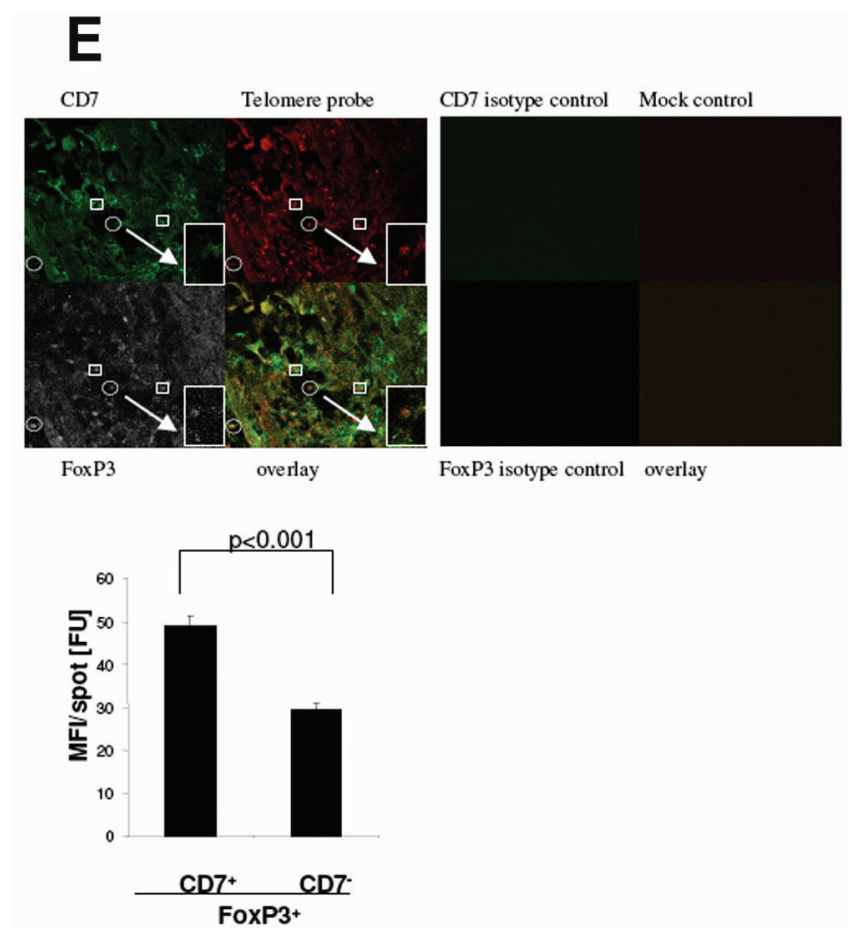

FIG. 5. (Continued).

\section{CD7- Treg cells express homing receptors directing them into peripheral organs}

We asked whether the striking differences in the functional capacities of $\mathrm{CD}^{+}$and $\mathrm{CD} 7^{-}$Treg cells are reflected by different tissue distributions. Therefore, we monitored the expression of a panel of surface markers associated with homing and migration (Table 1). CCR7 was expressed in less numbers and at lower levels on $\mathrm{CD}^{-}{ }^{-}$compared to the $\mathrm{CD} 7^{+}$ Treg cells. C-C chemokine receptor type 7 (CCR7)-deficient $\mathrm{T}$ cells are reported to be prone to persist in the skin by their inability to emigrate into lymph and back to blood. ${ }^{29}$ In line with that, cutaneous lymphocyte antigen (CLA), associated with skin homing, ${ }^{30}$ was expressed in higher frequencies and at higher levels in $\mathrm{CD}^{-}$compared to $\mathrm{CD}^{+}$Treg cells. CD31, a marker expressed by naïve Treg cells, ${ }^{31}$ was expressed on slightly higher numbers of cells and in higher levels by $\mathrm{CD}^{+}$ compared to $\mathrm{CD}^{-}$Treg cells. Integrins $\alpha 4 \beta 1$ and $\alpha 4 \beta 7$ are receptors for $\mathrm{T}$ cell migration into inflamed tissues and intestinal mucosal sites, respectively. ${ }^{32,33}$ Integrin $\alpha 4 \beta 1$ was more predominantly expressed on $\mathrm{CD}^{-}$than on $\mathrm{CD} 7^{+}$Treg cells, whereas integrin $\alpha 4 \beta 7$ was nearly equally expressed in both Treg cell subsets. The chemokine receptor CCR4, associated with trafficking of specialized cutaneous memory $\mathrm{T}$ cells to the skin, ${ }^{30}$ was expressed on nearly all $\mathrm{CD}^{-}$Treg cells, whereas $77 \%$ of $\mathrm{CD}^{+}$Treg cells express CCR4. In line with that, the chemokine receptor CCR10, associated with skin-homing of $\mathrm{T}$ cells, ${ }^{34}$ was expressed on a significantly higher percentage and on higher levels of $\mathrm{CD}^{-}$compared to $\mathrm{CD}^{+}$Treg cells. CD103, associated with intestinal memory cells, ${ }^{35}$ was not detectable on $\mathrm{CD}^{-}$Treg cells, whereas some $\mathrm{CD}^{+}$Treg cells expressed CD103. We found the same pattern of homing receptors on ex vivo-isolated and on in vitro-generated $\mathrm{CD}^{-}$Treg cells. Taken together, $\mathrm{CD}^{-}$Treg cells display a set of homing receptors indicating that these cells home to the skin, migrate into inflamed tissues, and persist in the periphery.

\section{CD7- Treg cells accumulate in chronic inflammatory skin lesions}

We monitored lymphocyte infiltrates of chronic inflammatory skin lesions including lichen ruber, atopic dermatitis, and psoriasis for the presence of $\mathrm{CD}^{-}$and $\mathrm{CD}^{+}$Treg cells (Fig. 5). Recording of $\mathrm{CD}^{+}{ }^{+} \mathrm{CD} 25^{+} \mathrm{FoxP}^{+}$Treg cell subsets in situ by immunofluorescence staining revealed that $\mathrm{CD}^{-}$Treg cells accumulate in these chronic inflammatory skin lesions compared to their distribution in the peripheral blood. In lichen ruber and atopic dermatitis, $\mathrm{CD}^{-}$ Treg cells constituted $90 \%$ and $75 \%$, respectively, of infiltrating Treg cells, whereas these cells represent less than $10 \%$ of Treg cells in the peripheral blood. In the reactive lymph node, for comparison, $\mathrm{CD}^{-}$Treg cells were not significantly increased compared to their distribution in the peripheral blood. Nearly all FoxP3 ${ }^{+} \mathrm{T}$ cells coexpress $\mathrm{CD} 4$ and CD25, but have downregulated CD127 (IL-7R $\alpha$ ) expression. Quantitative recording of FoxP3 expression in situ confirmed that $\mathrm{CD}^{-}$Treg cells expressed FoxP3 at lower levels per cell compared to $\mathrm{CD}^{+} \mathrm{T}$ cells within the same lesion, which is in accordance with the expression pattern of the corresponding Treg cells from the peripheral blood (Fig. $5 B$ ). Although these entities of chronic inflammatory pathologies were analyzed exemplarily, the survey clearly sustains our conclusion that $C D 7^{-}$Treg cells exhibit a marked tropism to the periphery compared to their distribution in the peripheral blood.

To monitor whether $\mathrm{CD}^{-}$Treg cells in the inflammatory lesion have a longer replicative history in comparison to the corresponding $\mathrm{CD}^{+}$Treg cells of the same lesion, we recorded the telomere lengths in situ by Q-FISH, combined with multicolor immunofluorescence analyses, to identify the respective cells. The assay was validated by analysis of telomere lengths of normal human diploid fibroblasts in cryostat sections of healthy skin, as recently described. ${ }^{36}$ Analyses of infiltrating cells in a psoriasis lesion is shown in Fig. 5E. Quantitative recording of MFIs of telomere spots revealed that $\mathrm{CD}^{+}{ }^{+} \mathrm{FoxP} 3^{+} \mathrm{CD}^{-} \mathrm{T}$ cells had shorter telomeres than the corresponding $\mathrm{CD}^{+} \mathrm{T}$ cells in the same lesion (Fig. $5 \mathrm{E})$. This sustains our conclusion that $\mathrm{CD}^{-}$Treg cells in chronic inflammatory lesions are in a more advanced replicative stage of $\mathrm{T}$ cell development than the corresponding $\mathrm{CD}^{+}$Treg cells.

\section{Discussion}

Recently, repetitive antigen encounter together with a strong CD28 signal were reported to stimulate the ex vivo amplification of Treg cells, ${ }^{3}$ the consequences of which, however, remained unknown. Here we have revealed that extensive TCR/CD28-triggered proliferation of human Treg cells results in altered functional capacities, including reduced suppressor activity, secretion of IL-4, display of markers associated with late memory and immunosenescence, and expression of homing receptors targeting these cells to the periphery. One additional hallmark of extensively am- 


\section{peripheral blood}

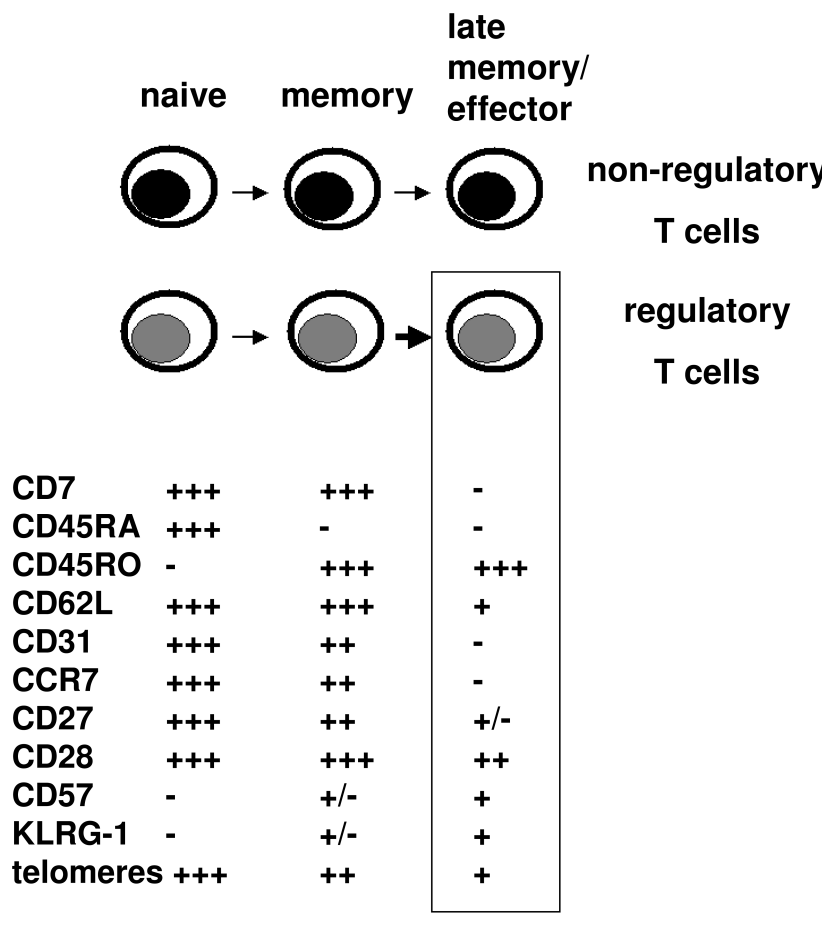

FIG. 6. Proposed model of late Treg cell differentiation. Treg cells constitute a separate branch of the $\mathrm{T}$ cell lineage and undergo positive selection in the thymus, which is mediated by high-affinity interactions of the $\mathrm{T}$ cell receptor and yet undefined additional signals. After entering into circulation and peripheral presentation of antigen, naïve Treg cells differentiate into memory-like Treg cells. Chronic antigen stimulation, however, drives late memory differentiation of Treg cells with altered functional capacities and homing properties.

plified T cells is the loss of CD7 expression, which is based on the following observations: (1) $\mathrm{CD}^{-} \mathrm{T}$ cells are generated in vitro from highly purified $\mathrm{CD}^{+}$Treg cells by extensive amplification. Accordingly, generation of $\mathrm{CD}^{-} \mathrm{T}$ cells requires multiple cell divisions because blocking $\mathrm{CD} 7^{+}$Treg cell proliferation prevented $\mathrm{CD}^{-} \mathrm{T}$ cell generation. (2) $\mathrm{CD}^{-}$ Treg cells isolated from peripheral blood have significantly shorter telomeres than $\mathrm{CD}^{+}$Treg cells of the same donor. Shorter telomeres were also found for tissue-infiltrating Treg cells in inflammatory lesions, as revealed by in situ monitoring of telomere lengths. Chronic inflammatory lesions may provide strong TCR and CD28 co-stimulatory signals, both required to induce proliferation of Treg cells. On the other hand, $\mathrm{CD}^{-}$Treg cells express less Ki67 compared to $\mathrm{CD}^{+}$Treg cells in the same lesion (unpublished data), implying that, upon extensive amplification, $\mathrm{CD}^{-}$Treg cells may have reached the Hayflick limit of proliferative capacities. CD7 ${ }^{-} \mathrm{T}$ cells generated in vitro from $\mathrm{CD}^{+}$Treg cells still exhibit functional attributes of regulatory $\mathrm{T}$ cells because they express FoxP3 and execute suppressive activities toward allogeneic $\mathrm{CD} 4{ }^{+} \mathrm{CD} 45 \mathrm{RO}^{+} \mathrm{CD} 25^{-} \mathrm{T}$ cells as do the $e x$ vivo isolated $\mathrm{CD}^{-}$Treg cells. The suppressive capacity of $\mathrm{CD}^{-}$Treg cells, however, is lower than that of $\mathrm{CD}^{+}$Treg cells, a result that was found consistently for both in vitrogenerated and ex vivo-isolated $\mathrm{CD}^{-}$Treg cells. Reduced suppressor capacities of $\mathrm{CD}^{-}$Treg cells are unlikely to be due to contamination with effector T cells, because after 2 weeks of amplification more than $98 \%$ of the cells exhibit the FoxP $3{ }^{+} \mathrm{CD} 25^{\text {high }}$ phenotype. In contrast to a recent report ${ }^{37}$ that $40 \%$ of cells after 2 weeks of proliferation lack FoxP3 expression, we used an extraordinarily strong TCR plus CD28 signal, provided by immobilized agonistic antibodies, in the presence of IL-2 to induce proliferation of Treg cells. ${ }^{3}$

$\mathrm{CD}^{-}$Treg cells with $\mathrm{CD} 4^{+} \mathrm{CD} 45 \mathrm{RO}^{+} \mathrm{CD} 25^{\text {high }}$ phenotype fulfill the criteria of cells in late memory development, which is summarized in Fig. 6. Both, homeostatic proliferation and repeated antigen exposure lead to late memory differentiation, which is characterized by loss of CD45RA and CCR7, by strong CD45RO and weak CD62L expression, and by shortened telomere lengths. ${ }^{38}$ The model moreover postulates that $\mathrm{CD}^{-}$Treg cells represent a late memory differentiation stage of Treg cells, but not a separate lineage of $\mathrm{T}$ cells. Accordingly, we did not detect CD7 ${ }^{+}$Treg cells with shorter telomere lengths than $\mathrm{CD}^{-}$Treg cells. Moreover, $\mathrm{CD}^{-}$Treg cells differ from Tr1 cells as follows: lower levels of IL-10 are secreted, no TGF- $\beta 1$ is secreted, but high levels of IL-4 are secreted, whereas Tr1 cells are characterized by high levels of IL- 10 and TGF- $\beta 1$ and moderate amounts of IFN- $\gamma$ and IL-5 upon TCR stimulation. ${ }^{39}$

After extensive amplification, the suppressor capacities of CD7 ${ }^{-}$Treg cells are substantially reduced. This holds for both ex vivo-isolated and in vitro-generated CD7- Treg cells. Reduced suppressor capacities of $\mathrm{CD}^{-}$Treg cells are associated with reduced FoxP3, CD27, and CD31 expression. Reduction in suppressor capacities upon extensive ex vivo amplification of Treg cells is likely to have dramatic consequences for their efficacy in the adoptive immunotherapy of various autoaggressive diseases, including diabetes and transplant rejection. Consequently, therapeutic protocols should prefer short-term ex vivo amplification of Treg cells and/or depletion of $\mathrm{CD}^{-}$cells from the Treg cell transplant.

Recently, CD4 ${ }^{+} \mathrm{CD} 25^{\text {high }}$ Treg cells with diminished FoxP3 or CD27 expression were reported to exhibit reduced suppressor capacities, ${ }^{40-42}$ whereas CD $31^{+}$Treg cells are more potent suppressor cells. ${ }^{31}$ Accordingly, in healthy elderly subjects, CD7 ${ }^{-}$Treg cells correspondingly accumulate in the peripheral blood with aging (E.K. Meuer, unpublished observations), in patients with vigorous Th2 responses and in diseases with a long history of antigen stimulation, such as multiple sclerosis, type I diabetes, and psoriasis, Treg cells are reported to be associated with reduced suppressor activities. ${ }^{43,44}$ Repeated antigen stimulation and inflammatory conditions over a long time may result in the conversion from $\mathrm{CD}^{+}$to late memory $\mathrm{CD}^{-}$ Treg cells, which, due to their reduced suppressor capacities, contribute to a functional deficiency of the Treg cell compartment.

Interestingly, highly amplified Treg cells, exhibit a number of unique properties that are different from the majority of mature Treg cells, the most prominent of which is the expression of skin homing receptors. Amplified Treg cells lack CCR7, but express CLA, integrin $\alpha 4 \beta 1$, CCR4, and CCR10 capable of directing the cells to the periphery. Loss of CCR7 results in the inability of $\mathrm{CD} 4^{+} \mathrm{T}$ cells to emigrate from the 
skin back to the lymphoid organs. ${ }^{29}$ We found CD7 ${ }^{-}$Treg cells accumulated at high levels in inflammatory lesions in the periphery where they represent up to $90 \%$ of infiltrating Treg cells. In inflamed central organs like reactive lymph nodes, in contrast, these cells are not amplified compared to the peripheral blood. In situ analysis confirmed that $\mathrm{CD}^{+}{ }^{+} \mathrm{FoxP}^{+} \mathrm{CD}^{-} \mathrm{T}$ cells in chronic inflammatory skin lesions have shorter telomeres than the corresponding $\mathrm{CD}^{+}$ $\mathrm{T}$ cells within the same lesion.

These data sustain the concept that proliferation of Treg cells under chronic inflammatory conditions results in the accumulation of $\mathrm{CD}^{-}$Treg cells, which, due to lack of CCR7 expression, are unable to migrate back into the lymph system, thereby leading to their accumulation in the lesion. IL15 highly expressed in chronic inflammatory lesions ${ }^{45}$ prevents apoptosis of $\mathrm{CD}^{-}$Treg cells, thereby sustaining their accumulation in the lesion. IL-15 will, moreover, contribute to reduce the overall suppressor capacities of Treg cells as recently shown. ${ }^{42}$ Although highly amplified in numbers, $\mathrm{CD}^{-}$Treg cells are likely not to be capable to limit the immune reaction due to their reduced suppressor capacities. Quite the reverse, IL-4 secreted by CD7 ${ }^{-}$Treg cells sustains inflammatory reactions by recruitment of mast cells, which, for their part, are involved in the pathogenesis of a number of immunological skin diseases. ${ }^{46-48}$ In this context, extensive Treg cell amplification upon strong TCR/CD28 engagement is likely to sustain the inflammatory reaction due to driving mature Treg cells into the late memory $\mathrm{CD}^{-}$Treg cell compartment with reduced suppressor capacities und proinflammatory IL-4 secretion. Accordingly, Treg cells with IL-4 and IL-10 expression were recently found in the peripheral blood of patients with atopic dermatitis. ${ }^{49}$ Taken together, our data indicate that extensive amplification of Treg cells under chronic stimulatory conditions alters their functional properties dramatically and targets the cells to the periphery.

\section{Acknowledgments}

We would like to thank Anika Voss, Petra Hofmann, Birgit Hops, and Frank Steiger for technical support. We are gratefully to Dr. A. Banham (Nuffield Department of Clinical Laboratory Sciences, University of Oxford, Oxford, UK), Dr. H. P. Pircher (Institute of Immunology, Freiburg, Germany), and Dr. H. Derradji (Laboratory of Radiobiology, Belgian Nuclear Research Centre, SCK CEN, Mol, Belgium) for supplying us with antibodies and cell lines. Our study was supported by the Deutsche Forschungsgemeinschaft, Bonn, Cluster of Excellence "Cellular Stress Responses in AgingAssociated Diseases" (CECAD) and by the Koeln Fortune Program of the Faculty of Medicine, University of Cologne.

\section{References}

1. Levings MK, Allan S, d'Hennezel E, Piccirillo CA. Functional dynamics of naturally occurring regulatory $\mathrm{T}$ cells in health and autoimmunity. Adv Immunol 2006;92:119-155.

2. Walker MR, Carson BD, Nepom GT, Ziegler SF, Buckner JH. De novo generation of antigen-specific $\mathrm{CD} 4{ }^{+} \mathrm{CD} 25^{+}$regulatory T cells from human $\mathrm{CD} 4^{+} \mathrm{CD} 25^{-}$cells. Proc Natl Acad Sci USA 2005;102:4103-4108.

3. Hombach AA, Kofler D, Hombach A, Rappl G, Abken H. Effective proliferation of human regulatory $\mathrm{T}$ cells requires a strong costimulatory CD28 signal that cannot be substituted by IL-2. J Immunol 2007;179:7924-7931.

4. Hoffmann P, Eder R, Kunz-Schughart LA, Andreesen R, Edinger M. Large-scale in vitro expansion of polyclonal human $\mathrm{CD}^{+} \mathrm{CD} 25^{\text {high }}$ regulatory $\mathrm{T}$ cells. Blood 2004;104: 895-903.

5. Gregori S, Bacchetta R, Passerini L, Levings MK, Roncarolo MG. Isolation, expansion, and characterization of human natural and adaptive regulatory T cells. Methods Mol Biol 2007;380:83-105.

6. Boschiero L, Nacchia F, Fior F, Cordiano C, Tridente G, Bellisola G. Specific alloantigen self-control by regulatory $\mathrm{T}$ cells in organ transplantation: a review. Transplant Proc 2007;39:2013-2017.

7. Kang SM, Tang Q, Bluestone JA. CD4 ${ }^{+} \mathrm{CD} 25^{+}$regulatory $\mathrm{T}$ cells in transplantation: progress, challenges and prospects. Am J Transplant 2007;7:1457-1463.

8. Roncarolo MG, Battaglia M. Regulatory T-cell immunotherapy for tolerance to self antigens and alloantigens in humans. Nat Rev Immunol 2007;7:585-598.

9. Bluestone JA, Thomson AW, Shevach EM, Weiner HL. What does the future hold for cell-based tolerogenic therapy? Nat Rev Immunol 2007;7:650-654.

10. Stillwell R, Bierer BE. T cell signal transduction and the role of CD7 in costimulation. Immunol Res 2001;24:31-52.

11. Reinhold U, Abken H. CD4 ${ }^{+} \mathrm{CD}^{-} \mathrm{T}$ cells: a separate subpopulation of memory T cells? J Clin Immunol 1997;17: 265-271.

12. Van Lier RA, Brouwer M, Aarden LA. Signals involved in $\mathrm{T}$ cell activation. $\mathrm{T}$ cell proliferation induced through the synergistic action of anti-CD28 and anti-CD2 monoclonal antibodies. Eur J Immunol 1988;18:167-172.

13. Dieckmann D, Plottner H, Berchtold S, Berger T, Schuler G. Ex vivo isolation and characterization of $\mathrm{CD} 4{ }^{+} \mathrm{CD} 25^{+} \mathrm{T}$ cells with regulatory properties from human blood. J Exp Med 2001;193:1303-1310.

14. Kubach J, Lutter P, Bopp T, Stoll S, Becker C, Huter E, Richter C, Weingarten P, Warger T, Knop J, Müllner S, Wijdenes J, Schild H, Schmitt E, Jonuleit H. Human $\mathrm{CD} 4{ }^{+} \mathrm{CD} 25^{+}$regulatory $\mathrm{T}$ cells: proteome analysis identifies galectin-10 as a novel marker essential for their anergy and suppressive function. Blood 2007;110:1550-1558.

15. Roncador G, Brown PJ, Maestre L, Hue S, MartinezTorrecuadrada JL, Ling KL, Pratap S, Toms C, Fox BC, Cerundolo V, Powrie F, Banham AH. Analysis of FoxP3 protein expression in human $\mathrm{CD} 4{ }^{+} \mathrm{CD} 25^{+}$regulatory $\mathrm{T}$ cells at the single-cell level. Eur J Immunol 2005;35: 1681-1691.

16. Baecher-Allan C, Wolf E, Hafler DA. Functional analysis of highly defined, FACS-isolated populations of human regulatory CD4 ${ }^{+}$CD $25^{+}$T cells. Clin Immunol 2005;115:10-18.

17. Game DS, Hernandez-Fuentes MP, Lechler RI. Everolimus and Basiliximab permit suppression by human $\mathrm{CD} 4{ }^{+} \mathrm{CD} 25^{+}$ cells in vitro. Am J Transplant 2005;5:454-464.

18. Huong PL, Kolk AH, Eggelte TA, Verstijnen CP, Gilis H, Hendriks JT. Measurement of antigen specific lymphocyte proliferation using 5-bromo-deoxyuridine incorporation. An easy and low cost alternative to radioactive thymidine incorporation. J Immunol Methods 1991;140:243-248.

19. Rappl G, Schrama D, Hombach A, Meuer EK, Schmidt A, Becker JC, Abken H. CD7 ${ }^{-} \mathrm{T}$ cells are late memory cells generated from CD7 ${ }^{+} \mathrm{T}$ cells. Rejuvenation Res 2008;11:543-556.

20. Kapoor V, Telford WG. Telomere length measurement by fluorescence in situ hybridization and flow cytometry. Methods Mol Biol 2004;263:385-398. 
21. Hultdin M, Grönlund E, Norrback K, Eriksson-Lindström E, Just T, Roos G. Telomere analysis by fluorescence in situ hybridization and flow cytometry. Nucleic Acids Res 1998;26: 3651-3656.

22. Ferlicot S, Youssef N, Feneux D, Delhommeau F, Paradis V, Bedossa P. Measurement of telomere length on tissue sections using quantitative fluorescence in situ hybridization (Q-FISH). J Pathol 2003;200:661-666.

23. Ali AS, Chopra R, Robertson J, Testa NG. Detection of hTERT protein by flow cytometry. Leukemia 2000;14: 2176-2181.

24. Schmidt A, Ladage D, Steingen C, Brixius K, Schinköthe T, Klinz FJ, Schwinger RH, Mehlhorn U, Bloch W. Mesenchymal stem cells transmigrate over the endothelial barrier. Eur J Cell Biol 2006;85:1179-1188.

25. Voehringer D, Koschella M, Pircher H. Lack of proliferative capacity of human effector and memory $\mathrm{T}$ cells expressing killer cell lectin like receptor G1 (KLRG-1). Blood 2002; 100:3698-3702.

26. Mc Hugh RS, Whitters MJ, Piccirillo CA, Young DA, Shevach EM, Collins M, Byrne MC. CD4 ${ }^{+} \mathrm{CD} 25^{+}$immunoregulatory $\mathrm{T}$ cells: gene expression analysis reveals a functional role for the glucocorticoid-induced TNF receptor. Immunity 2002;16:311-323.

27. Valmori D, Merlo A, Souleimanian NE, Hesdorffer CS, Ayyoub M. A peripheral circulating compartment of natural naive CD4 ${ }^{+}$Tregs. J Clin Invest 2005;115:1953-1962.

28. Taams LS, Smith J, Rustin MH, Salmon M, Poulter LW, Akbar AN. Human anergic/suppressive $\mathrm{CD} 4{ }^{+} \mathrm{CD} 25^{+} \mathrm{T}$ cells: a highly differentiated and apoptosis-prone population. Eur J Immunol 2001;31:1122-1131.

29. Debes GF, Arnold CN, Young AJ, Krautwald S, Lipp M, Hay JB, Butcher EC. Chemokine receptor CCR7 required for T lymphocyte exit from peripheral tissues. Nat Immunol 2005;6:889-894.

30. Kupper TS, Fuhlbrigge RC. Immune surveillance in the skin: mechanisms and clinical consequences. Nat Rev Immunol 2004;4:211-222.

31. Haas J, Fritzsching B, Trübswetter P, Korporal M, Milkova L, Fritz B, Vobis D, Krammer PH, Suri-Payer E, Wildemann B. Prevalence of newly generated naive regulatory $\mathrm{T}$ cells (Treg) is critical for Treg suppressive function and determines Treg dysfunction in multiple sclerosis. J Immunol 2007;179:1322-1330.

32. Stassen M, Fondel S, Bopp T, Richter C, Müller C, Kubach J, Becker C, Knop J, Enk AH, Schmitt S, Schmitt E, Jonuleit $\mathrm{H}$. Human $\mathrm{CD} 25^{+}$regulatory T cells: two subsets defined by the integrins alpha 4 beta 7 or alpha 4 beta 1 confer distinct suppressive properties upon $\mathrm{CD}^{+} \mathrm{T}$ helper cells. Eur J Immunol 2004;34:1303-1311.

33. Berlin C, Berg EL, Briskin MJ, Andrew DP, Kilshaw PJ, Holzmann B, Weissman IL, Hamann A, Butcher EC. Alpha 4 beta 7 integrin mediates lymphocyte binding to the mucosal vascular addressin MAdCAM-1. Cell 1993;74:185-195.

34. Homey B, Alenius H, Müller A, Soto H, Bowman EP, Yuan W, Mc Evoy L, Lauerma AI, Assmann T, Bünemann E, Lehto M, Wolff H, Yen D, Marxhausen H, To W, Sedgwick J, Ruzicka T, Lehmann P, Zlotnik A. CCL27-CCR10 interactions regulate $\mathrm{T}$ cell-mediated skin inflammation. Nat Med 2002;8:157-165.

35. Johansson-Lindbom B, Agace WW. Generation of gut-homing $\mathrm{T}$ cells and their localization to the small intestinal mucosa. Immunol Rev 2007;215:226-242.

36. O'Sullivan JN, Finley JC, Risques RA, Shen WT, Gollahon KA, Moskovitz AH, Gryaznov S, Harley CB, Rabinovitch PS.
Telomere length assessment in tissue sections by quantitative FISH: image analysis algorithms. Cytometry Part A 2004;58A:120-131.

37. Crellin NK, Garcia RV, Levings MK. Flow cytometry-based methods for studying signaling in human $\mathrm{CD} 4^{+} \mathrm{CD} 25^{+} \mathrm{FoxP} 3^{+}$ T regulatory cells. J Immunol Methods 2007;324:92-104.

38. Dejaco C, Duftner C, Schirmer M. Are regulatory T cells linked with aging? Exp Gerontol 2006;41:339-345.

39. Groux H, O' Garra A, Bigler M, Rouleau M, Antonenko S, de Vries JE, Roncarolo MG. A CD4 ${ }^{+}$T-cell subset inhibits antigen-specific $\mathrm{T}$ cell responses and prevents colitis. Nature 1997;389:737-742.

40. Venken K, Hellings N, Thewissen M, Somers V, Hensen K, Rummens JL, Medaer R, Hupperts R, Stinissen P. Compromised $\mathrm{CD} 4^{+} \mathrm{CD} 25^{\text {high }}$ regulatory T-cell function in patients with relapsing-remitting multiple sclerosis is correlated with a reduced frequency of FoxP3-positive cells and reduced FoxP3 expression at the single-cell level. Immunology 2008;123:79-89.

41. Valencia X, Yarboro C, Illei G, Lipsky PE. Deficient $\mathrm{CD} 4{ }^{+} \mathrm{CD} 25^{\text {high }} \mathrm{T}$ regulatory cell function in patients with active systemic lupus erythematosus. J Immunol 2007;178: 2579-2588.

42. Ruprecht CR, Gattorno M, Ferlito F, Gregorio A, Martini A, Lanzavecchia A, Sallusto F. Coexpression of CD25 and CD27 identifies $\mathrm{FoxP}^{+}$regulatory $\mathrm{T}$ cells in inflamed synovia. J Exp Med 2005;201:1793-1803.

43. Tsaknaridis L, Spencer L, Culbertson N, Hicks K, LaTocha D, Chou YK, Whitham RH, Bakke A, Jones RE, Offner H, Bourdette DN, Vandenbark AA. Functional assay for human $\mathrm{CD} 4{ }^{+} \mathrm{CD} 25^{+}$Treg cells reveals an age-dependent loss of suppressive activity. J Neurosci Res 2003;74:296-308.

44. Taams LS, Palmer DB, Akbar AN, Robinson DS, Brown Z, Hawrylowicz CM. Regulatory T cells in human disease and their potential for therapeutic manipulation. Immunology 2006;118:1-9.

45. Budagian V, Bulanova E, Paus R, Bulfone-Paus S. IL-15/IL15 receptor biology: a guided tour through an expanding universe. Cytokine Growth Factor Rev 2006;17:259-280.

46. Navi D, Saegusa J, Liu FT. Mast cells and immunological skin diseases. Clin Rev Allergy Immunol 2007;33:144-155.

47. Fischer M, Harvima IT, Carvalho RF, Möller C, Naukkarinen A, Enblad G, Nilsson G. Mast cell CD30 ligand is upregulated in cutaneous inflammation and mediates degranulation-independent chemokine secretion. J Clin Invest 2006;116:2748-2756.

48. Zalewska A, Brzezinska-Blaszczyk E, Omulecki A, Pietrzak A. Functional studies of skin mast cells in lichen planus. Arch Dermatol Res 1997;289:261-264.

49. Bellinghausen I, Klostermann B, Knop J, Saloga J. Human $\mathrm{CD} 4{ }^{+} \mathrm{CD} 25^{+} \mathrm{T}$ cells derived from the majority of atopic donors are able to suppress Th1 and Th2 cytokine production. J Allergy Clin Immunol 2003;111:862-868.

Address for correspondence and reprints: Univ.-Prof. Dr. Hinrich Abken Center for Molecular Medicine Cologne University of Cologne Kerpener Str. 62, D-50924 Köln, Germany

E-mail: hinrich.abken@uk-koeln.de

Received: March 17, 2008 Accepted: July 31, 2008 